\title{
Omasal Flow of Soluble Proteins, Peptides, and Free Amino Acids in Dairy Cows Fed Diets Supplemented with Proteins of Varying Ruminal Degradabilities ${ }^{1}$
}

\author{
S. M. Reynal, ${ }^{\star 2,3}$ I. R. Ipharraguerre,$\dagger^{4}$ M. Liñeiro, $\dagger^{5}$ A. F. Brito, ${ }^{\star 6}$ G. A. Broderick, $\ddagger$ and J. H. Clark $\dagger$ \\ *Department of Dairy Science, University of Wisconsin, Madison 53706 \\ †Department of Animal Sciences, University of Illinois, Urbana 61801 \\ ¥Agricultural Research Service, USDA, US Dairy Forage Research Center, University of Wisconsin, Madison 53706
}

\begin{abstract}
Three ruminally and duodenally cannulated cows were assigned to an incomplete $4 \times 4$ Latin square with four 14-d periods and were fed diets supplemented with urea, solvent soybean meal, xylosetreated soybean meal (XSBM), or corn gluten meal to study the effects of crude protein source on omasal canal flows of soluble AA. Soluble AA in omasal digesta were fractionated by ultrafiltration into soluble proteins greater than $10 \mathrm{kDa}(10 \mathrm{~K})$, oligopeptides between 3 and $10 \mathrm{kDa}(3-10 \mathrm{~K})$, peptides smaller than 3 $\mathrm{kDa}$ (small peptides), and free AA (FAA). Omasal flow of total soluble AA ranged from 254 to $377 \mathrm{~g} / \mathrm{d}$ and accounted for 9.2 to $15.9 \%$ of total AA flow. Averaged across diets, flows of AA in 10K, 3-10K, small peptides, and FAA were $29,217,50$, and $5 \mathrm{~g} / \mathrm{d}$, respectively, and accounted for $10.3,71.0,17.5$, and $1.6 \%$ of the total soluble AA flow. Cows with diets supplemented with solvent soybean meal had higher flows of Met, Val, and total AA associated with small peptides than those whose diets were supplemented with XSBM, whereas supplementation with corn gluten meal resulted in higher total small peptide-AA flows than did XSBM. Averaged across diets, 27, 75, and 93\% of soluble AA in $10 \mathrm{~K}, 3-10 \mathrm{~K}$, and peptides plus FAA flowing out of the rumen were of dietary origin. On average, $10 \%$ of
\end{abstract}

\footnotetext{
Received March 20, 2006.

Accepted September 20, 2006.

${ }^{1}$ Mention of any trademark or proprietary product in this paper does not constitute a guarantee or warranty of the product by the USDA or the Agricultural Research Service and does not imply its approval to the exclusion of other products that may also be suitable.

${ }^{2}$ Corresponding author: sreynal@wisc.edu

${ }^{3}$ Current address: Agricultural Research Service, USDA, US Dairy Forage Research Center, 1925 Linden Dr., Madison, WI 53706.

${ }^{4}$ Current address: Lucta S. A., P. O. Box 1112, Barcelona 08080, Spain.

${ }^{5}$ Current address: Granja Tres Arroyos, Buenos Aires, Argentina.

${ }^{6}$ Current address: Dairy and Swine Research and Development Center, Agriculture and Agri-Food Canada, Lennoxville, Quebec, Canada J1M $1 \mathrm{Z3}$.
}

the total AA flow from the rumen was soluble AA from dietary origin, indicating a substantial escape of dietary soluble $\mathrm{N}$ from ruminal degradation. Omasal concentrations and flows of soluble small peptides isolated by ultrafiltration were substantially smaller than most published ruminal small peptide concentrations and outflows measured in acid-deproteinized supernatants of digesta.

Key words: dairy cow, omasal flow, soluble amino acid, peptide

\section{INTRODUCTION}

Protein degradation by ruminal microbes results in the formation of ammonia, and peptides and AA are intermediates in this process. Ammonia that accumulates in excess of microbial requirements is converted to urea in the liver and excreted in the urine, resulting in inefficient $\mathrm{N}$ utilization by the animal (Broderick et al., 1991). In vitro and in vivo evidence suggests that the rate-limiting step in ruminal protein degradation may be peptide hydrolysis (Russell et al., 1983; Chen et al., 1987b), and the degradation rate may depend on the degradability (Broderick and Wallace, 1988) and AA profile of the protein (Yang and Russell, 1992). Mounting evidence indicates that peptides and free AA (FAA) stimulate microbial yield and fermentation (Argyle and Baldwin, 1989; Chikunya et al., 1996; Carro et al., 1999). Furthermore, peptides (mainly diand tripeptides) may contribute significantly to AA absorption from the intestines of ruminants (Remond et al., 2000) and may have nutritional benefits for the host animal (Webb and Matthews, 1998). Therefore, alteration of proteolysis and peptide formation in the rumen by dietary manipulation may have nutritional benefits for both ruminal microbes and the host animal, improving utilization of dietary $\mathrm{N}$ for productive purposes.

New systems of ruminant ration formulation (AFRC, 1992; Sniffen et al., 1992; NRC, 2001) rely on rate constants for ruminal protein degradation and 
passage. Most commonly, the in situ method has been used to assess the kinetics of protein degradation in the rumen. However, this technique has theoretical limitations that call its accuracy into question (Broderick et al., 1991). Two major concerns are 1) that the rates of ruminal degradation of the soluble $\mathrm{N}$ fraction (fraction A) from all feeds incubated in situ are assumed to be infinite and 2) that the portion of dietary protein that is degraded in the rumen (fraction B) is assumed to be entirely used for microbial protein synthesis or production of ammonia and carbon skeletons, or both. However, if a portion of these fractions (i.e., $\mathrm{A}$ and $\mathrm{B}$ ) escapes ruminal degradation as soluble proteins, peptides, and free AA, the validity of these assumptions may not hold true.

Despite the potential nutritional and metabolic importance of the ruminal peptide pool, most of the information available on degradation and metabolism of soluble $\mathrm{N}$ fractions in ruminants is based on methodologies that may be unreliable. Peptide AA are usually determined by quantitation of free AA concentrations before and after hydrolysis of samples previously deproteinized by acid precipitation. However, a substantial proportion of the soluble proteins may remain in solution after acid deproteinization (Moughan et al., 1990) and the use of strong acids may result in partial hydrolysis of proteins and release of peptides, leading to an overestimation of the peptide $\mathrm{N}$ fraction (Seal and Parker, 1998; Choi et al., 2002a). Moreover, the extent of this chemical deproteinization depends on the type and concentration of the acid used (Greenberg and Shipe, 1979; Moughan et al., 1990; Butts et al., 1991) and on the structure of the proteins being precipitated (Bhatty, 1972; Greenberg and Shipe, 1979). Because the acid type (e.g., perchloric, trichloroacetic, sulfosalicylic), concentration, and times and temperatures of incubation vary widely among published methodologies, interpretation and comparison of data obtained using these techniques should be done with caution. Therefore, a more reliable and reproducible method is needed to study the nutritional and metabolic significance of the flow of soluble AA from the rumen and to test the validity of the in situ technique for estimating rates of protein degradation in the rumen.

The objective of this experiment was to study the effect of feeding diets differing in concentration, ruminal degradability, and source of protein supplement on flows of soluble proteins, peptides, and FAA at the omasal canal with special emphasis on the methodology used for soluble $\mathrm{N}$ fractionation.
Table 1. Ingredient and chemical composition of experimental diets ${ }^{1}$

\begin{tabular}{|c|c|c|c|c|}
\hline \multirow[b]{2}{*}{ Item } & \multicolumn{4}{|c|}{ Diet } \\
\hline & $\begin{array}{l}\text { A } \\
\text { (urea) }\end{array}$ & $\begin{array}{l}\text { B } \\
(\mathrm{SSBM})\end{array}$ & $\begin{array}{l}\mathrm{C} \\
(\mathrm{XSBM})\end{array}$ & $\begin{array}{l}\mathrm{D} \\
(\mathrm{CGM})\end{array}$ \\
\hline & & - $(\%$ o & $\mathrm{DM})$ & \\
\hline \multicolumn{5}{|l|}{ Ingredients } \\
\hline Alfalfa silage & 25.0 & 25.0 & 25.0 & 25.0 \\
\hline Corn silage & 35.0 & 35.0 & 35.0 & 35.0 \\
\hline Shelled corn, ground & 34.8 & 32.1 & 32.7 & 28.6 \\
\hline Urea & 2.3 & - & - & - \\
\hline Solvent soybean meal & - & 5.2 & - & - \\
\hline Xylose-treated soybean meal & - & - & 4.6 & - \\
\hline Corn gluten meal & - & - & - & 8.5 \\
\hline Salt & 0.14 & 0.14 & 0.14 & 0.14 \\
\hline Sodium bicarbonate & 1.0 & 1.0 & 1.0 & 1.0 \\
\hline Calcium diphosphate & 0.60 & 0.41 & 0.42 & 0.45 \\
\hline Limestone & 0.60 & 0.60 & 0.65 & 0.65 \\
\hline Sodium sulfate & 0.14 & 0.14 & 0.14 & 0.14 \\
\hline Magnesium oxide & 0.14 & 0.14 & 0.14 & 0.18 \\
\hline Mineral and vitamin $\operatorname{mix}^{2}$ & 0.25 & 0.25 & 0.25 & 0.25 \\
\hline \multicolumn{5}{|l|}{ Chemical composition } \\
\hline $\mathrm{DM}, \%$ & 50.4 & 50.4 & 50.7 & 49.6 \\
\hline $\mathrm{CP}, \%$ of $\mathrm{DM}$ & 19.7 & 15.8 & 15.3 & 18.2 \\
\hline $\mathrm{NDF}, \%$ of DM & 31.8 & 28.6 & 30.0 & 28.1 \\
\hline $\mathrm{ADF}, \%$ of $\mathrm{DM}$ & 20.0 & 17.8 & 17.5 & 17.6 \\
\hline Starch, \% of DM & 28.1 & 28.1 & 27.2 & 26.1 \\
\hline TAAN, \% of total $\mathrm{N}$ & 35.5 & 68.8 & 64.4 & 82.3 \\
\hline $\mathrm{NPN}, \%$ of TN & 64.5 & 31.2 & 35.6 & 17.7 \\
\hline $\mathrm{NFC}^{3} \%$ of $\mathrm{DM}$ & 41.2 & 44.8 & 45.5 & 42.5 \\
\hline $\mathrm{NE}_{\mathrm{L}},{ }^{3} \mathrm{Mcal} / \mathrm{kg}$ & 1.57 & 1.59 & 1.56 & 1.58 \\
\hline
\end{tabular}

${ }^{1} \mathrm{SSBM}=$ solvent soybean meal; XSBM = xylose-treated soybean meal; CGM = corn gluten meal; TAAN = total AA-N.

${ }^{2}$ Contained $5.0 \% \mathrm{Mg}, 7.5 \% \mathrm{~K}, 10.0 \% \mathrm{~S}, 3.0 \% \mathrm{Zn}, 3.0 \% \mathrm{Mn}, 2.0 \%$ $\mathrm{Fe}, 0.5 \% \mathrm{Cu}, 0.025 \% \mathrm{I}, 0.015 \% \mathrm{Se}, 0.004 \% \mathrm{Co}, 2,200 \mathrm{IU}$ of vitamin $\mathrm{A} / \mathrm{g}, 660 \mathrm{IU}$ of vitamin $\mathrm{D}_{3} / \mathrm{g}$, and $8 \mathrm{IU}$ of vitamin $\mathrm{E} / \mathrm{g}$.

${ }^{3}$ Estimated using the NRC (2001) model.

\section{MATERIALS AND METHODS}

\section{Animal Management, Experimental Design, and Sampling}

Three ruminally and duodenally cannulated lactating Holstein cows averaging $154( \pm 92)$ DIM at the beginning of the trial were assigned to an incomplete 4 $\times 4$ Latin square with four 14-d periods and were fed one of 4 diets differing in the proportion and source of the protein supplement. Each cow was randomly assigned to 1 of 3 treatment sequences in which a treatment never followed the same treatment more than once. The TMR contained (DM basis) 35\% corn silage, $25 \%$ alfalfa silage, $2.7 \%$ vitamins and minerals, and $37 \%$ concentrate [CP supplement plus ground shelled corn (GSC)]. Diets (Table 1) differed in the proportion and source of CP supplement: $\operatorname{diet} \mathrm{A}$ (urea; $34.8 \%$ GSC, $2.3 \%$ urea); diet B [32.1\% GSC, $5.2 \%$ solvent soybean meal (SSBM)]; diet C [32.7\% GSC, 4.6\% xylose-treated SBM (XSBM; SoyPass, LignoTech USA, Inc., Rothschild, WI)]; or diet D [28.6\% GSC, $8.5 \%$ corn gluten meal (CGM)]. Details of the surgical 
procedures, animal management, and sampling and analyses of silages, concentrates, TMR, and orts are described by Ipharraguerre et al. (2007).

Milk weights were recorded at each milking throughout the trial. Milk samples were taken at each milking during the last $3 \mathrm{~d}$ of each period, preserved with 2-bromo-2-nitropropane-1,3-diol, and stored at $4^{\circ} \mathrm{C}$. Samples were sent to Dairy One Cooperative Inc. (Ithaca, NY) for analyses of fat, true protein, and MUN by infrared procedures (Foss 4000; Foss North America, Eden Prairie, MN). Samples of ruminal fluid were collected at $1800,1900,2000$, and $2200 \mathrm{~h}$ on d 8 and at 0100, 0500, 0600, 0700, 0800, 1000, and 1300 $\mathrm{h}$ on $\mathrm{d} 9$ of each period. Ruminal samples were collected from multiple sites in the rumen and $\mathrm{pH}$ of the ruminal fluid was measured immediately by a glass electrode (Advanced Portable $\mathrm{pH} / \mathrm{mV} / \mathrm{Ion}$ Meter, model AP25; Denver Instrument, Göttingen, Germany); 10-mL subsamples were then preserved by addition of $0.2 \mathrm{~mL}$ of $50 \%$ (vol/vol) $\mathrm{H}_{2} \mathrm{SO}_{4}$ and stored at $-20^{\circ} \mathrm{C}$. Just before analysis, samples were thawed, centrifuged $(15,000 \times$ $\mathrm{g}, 4^{\circ} \mathrm{C}, 15 \mathrm{~min}$ ), and analyzed for ammonia and total FAA (Broderick and Kang, 1980) using flow-injection analysis (Dual-Channel QuikChem 8000 FIA; Lachat Instruments, Milwaukee, WI), and for VFA (Brotz and Schaefer, 1987).

Digesta flow leaving the rumen was quantified using the omasal sampling technique developed by Huhtanen et al. (1997) as modified by Ahvenjärvi et al. (2000). Indigestible NDF, CoEDTA, and $\mathrm{YbCl}_{3}$ were used as markers to assess digesta flows at the omasal canal, and the external microbial marker ${ }^{15} \mathrm{~N}$ was used to measure microbial $\mathrm{N}$ flows from the rumen. Details on marker preparation, infusion, and analyses are reported in Ipharraguerre et al. (2007). Omasal spot samples of $355 \mathrm{~mL}$ were collected from the omasal canal on $\mathrm{d} 12,13$, and 14 of each period such that the 12 samples represented a 24 -h feeding cycle over $3 \mathrm{~d}$. Each spot sample was swirled vigorously and poured into 3 containers to obtain subsamples of 200, 125 , and $30 \mathrm{~mL}$. The $125-\mathrm{mL}$ subsamples were pooled over the 4 daily sampling times to yield one $500-\mathrm{mL}$ composite from each cow on each sampling day, and the composite sample was processed later that day to isolate bacteria. The $200-\mathrm{mL}$ subsamples were pooled and stored at $-20^{\circ} \mathrm{C}$ as they were collected over all 12 sampling times, to yield one 2.4-L omasal composite from each cow in each period. The $30-\mathrm{mL}$ subsamples were squeezed through 1 layer of $0.45-\mu \mathrm{m}$ Dacron mesh, the filtrate centrifuged at $50,000 \times g$ for $15 \mathrm{~min}$ at $5^{\circ} \mathrm{C}$ to precipitate particulate matter, and the supernatant was held on ice until stored at $-80^{\circ} \mathrm{C}$ within $30 \mathrm{~min}$ of collection for later determination of soluble $\mathrm{N}$ flow at the omasal canal.
The 2.4-L pooled omasal composites were separated into 3 digesta phases: fluid phase (FP), large particle phase (LP), and small particle phase (SP). Concentrations of $\mathrm{Co}, \mathrm{Yb}$, and indigestible NDF in LP and SP and of $\mathrm{Co}$ and $\mathrm{Yb}$ in $\mathrm{FP}$ were used to mix DM from freeze-dried FP, SP, and LP in the correct proportions to reconstitute the omasal true digesta (OTD) flowing out of the rumen based on the triple-marker method of France and Siddons (1986). Digesta phase separation and marker analyses are described in Ipharraguerre et al. (2007). Aliquots of the SP and LP phases were mixed in the correct proportions based on the markers to yield a 2-g sample that was ground through a 0.5-mm screen with a Udy Cyclone Sample mill (Udy Corporation, Fort Collins, CO) and defined as small plus large particles $(\mathbf{S P}+\mathbf{L P})$. Feed and OTD samples were sequentially ground through 2 - and $1-\mathrm{mm}$ screens using a Wiley mill (Arthur H. Thomas, Philadelphia, PA) and analyzed for $\mathrm{DM}$ at $105^{\circ} \mathrm{C}$; ash and OM (AOAC, 1980); and total $\mathrm{N}$ using a combustion assay (Leco FP-2000 N Analyzer; Leco Instruments, Inc., St. Joseph, MI).

At the end of each sampling day, the $500-\mathrm{mL}$ omasal composites were separated to yield fluid and particle phases that were equivalent to the FP and the SP + LP phases from the 2.4-L composites, respectively. Fluid-associated bacteria (FAB) and particle-associated bacteria (PAB) were isolated from these fluid and particle phases, respectively, and pooled over the 3 sampling days of each period to yield one composite each of FAB and PAB per cow per period. The OTD, FAB, PAB, and individual feeds were analyzed for 16 AA after hydrolysis in $6 \mathrm{~N} \mathrm{HCl}$ (Nagel and Broderick, 1992), using norleucine as the internal standard and ion-exchange chromatography with ninhydrin detection (Beckman 6300 Amino Acid Analyzer; Beckman Instruments, Inc., Palo Alto, CA). Samples of ${ }^{15} \mathrm{~N}$ natural background, FAB, PAB, FP, and SP + LP $(100 \mu \mathrm{g}$ of $\mathrm{N})$ were weighed into tin cups $(5 \times 9 \mathrm{~mm}$; Costech Analytical Technologies, Valencia, CA) and, after addition of $50 \mu \mathrm{L}$ of $72-\mathrm{mM} \mathrm{K}_{2} \mathrm{CO}_{3}$ solution, were placed in a $60^{\circ} \mathrm{C}$ oven to volatilize ammonia. Samples were analyzed for NAN and ${ }^{15} \mathrm{~N}$ enrichment of NAN by isotope ratio mass spectrometry (Stable Isotope Facility, Department of Agronomy and Range Science, University of California-Davis, Davis, CA). Other details about collection, processing, and analysis of samples of OTD, FAB, and PAB are reported in Ipharraguerre et al. (2007).

\section{Fractionation of Soluble N Fractions}

At the end of the experiment, the $30-\mathrm{mL}$ omasal subsamples were fractionated as outlined in Figure 1. 


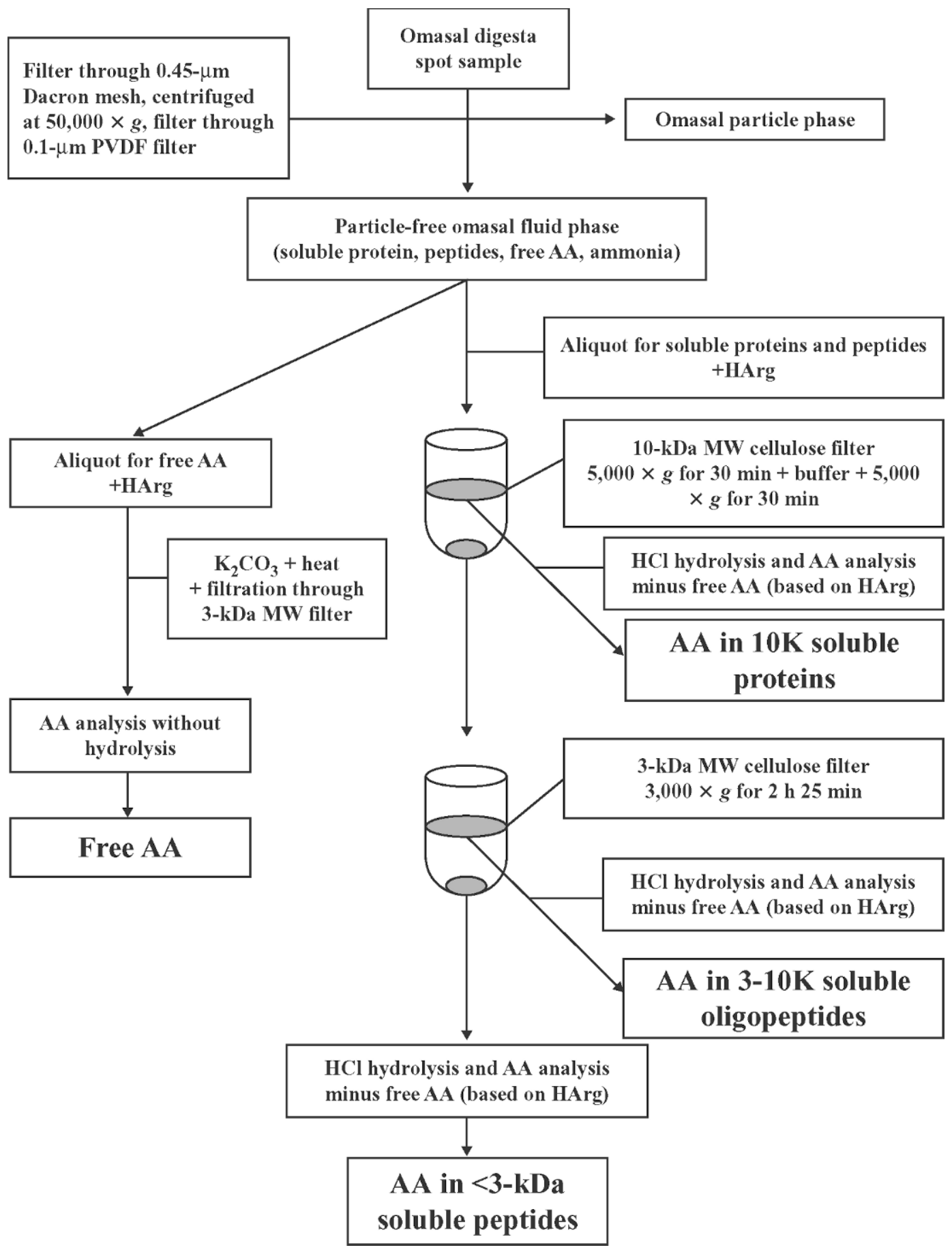

Figure 1. Fractionation and analysis of soluble proteins, peptides, and free AA in omasal digesta. PVDF = polyvinylidene fluoride; HArg = homoarginine (internal standard); $\mathrm{MW}=$ molecular weight; $3-10 \mathrm{~K}=3$ to $10 \mathrm{kDa} ; 10 \mathrm{~K}=10 \mathrm{kDa}$.

Samples were slowly thawed in an ice bath and a 13.5$\mathrm{mL}$ aliquot was centrifuged at $50,000 \times \mathrm{g}$ for $15 \mathrm{~min}$ at $0^{\circ} \mathrm{C}$. The supernatant was filtered through a 0.1 $\mu \mathrm{m}$ filter (Millex-VV, no. SLVV033RB, PVDF filter, Millipore, Billerica, MA) and $5 \mathrm{~mL}$ of filtrate was saved for later analysis of FAA. A 5.4-mL aliquot of filtrate was pipetted into a tared $10-\mathrm{kDa}$ molecular weight (MW) cut-off ultracentrifugation filter with a cellulose membrane (Amicon-Ultra, no. UFC901024, Millipore) and $0.6 \mathrm{~mL}$ of $2 \mathrm{~m} M$ homoarginine solution was added 
as an internal standard for determination of FAA in retentates. This filtration device was centrifuged at $5,000 \times g$ for $30 \mathrm{~min}$ at $5^{\circ} \mathrm{C}$. Then, $6 \mathrm{~mL}$ of McDougall's buffer (McDougall, 1948) was added to the retentate and the device was centrifuged again at 5,000 $\times g$ for $30 \mathrm{~min}$ at $5^{\circ} \mathrm{C}$. The vials from the filtration device containing filtrate and retentate solutions were weighed and their weights recorded for recovery calculations. A $0.5-\mathrm{mL}$ aliquot of retentate was transferred to a glass culture tube for later hydrolysis and determination of AA in soluble proteins greater than $10 \mathrm{kDa}$ $(\mathbf{1 0 K})$ in omasal digesta. The remaining retentate solution was stored at $-80^{\circ} \mathrm{C}$ for later analysis. An 8-mL aliquot of filtrate was transferred to a tared $3-\mathrm{kDa}$ MW cut-off ultracentrifugation filter with a cellulose membrane (Centriprep-3, no. 4302, Millipore) and centrifuged once at $3,000 \times g$ at $5^{\circ} \mathrm{C}$ for $65 \mathrm{~min}$ and then 4 more times for $20 \mathrm{~min}$ at the same speed and temperature. Filtrate and retentate vials containing their corresponding solutions were weighed and their weights recorded for recovery calculations. A $0.25-\mathrm{mL}$ aliquot of retentate and a 1-mL aliquot of filtrate were transferred to glass culture tubes for later hydrolysis and determination of individual AA in soluble oligopeptides between 3 and $10 \mathrm{kDa}(\mathbf{3 - 1 0 K})$, and peptides of less than $3 \mathrm{kDa}$ (called small peptides hereafter) plus FAA. The remaining retentates and filtrates were stored at $-80^{\circ} \mathrm{C}$ for later analysis. To the tubes containing $0.5 \mathrm{~mL}$ of $10 \mathrm{~K}$ retentate and $0.5 \mathrm{~mL}$ of small peptides plus FAA filtrate, $0.625 \mathrm{~mL}$ of $12 \mathrm{~N} \mathrm{HCl}$ with $1 \mathrm{~g} / \mathrm{L}$ of phenol and $0.125 \mathrm{~mL}$ of $1 \mathrm{~m} M$ norleucine were added. To tubes containing $0.25 \mathrm{~mL}$ of $3-10 \mathrm{~K}$ retentate, $312.5 \mu \mathrm{L}$ of $12 \mathrm{~N} \mathrm{HCl}$ with $1 \mathrm{~g} / \mathrm{L}$ of phenol and $62.5 \mu \mathrm{L}$ of $1 \mathrm{~m} M$ norleucine were added. All tubes were flushed with $\mathrm{N}_{2}$ gas for $20 \mathrm{~s}$, sealed with Teflon tape and capped tightly, and heated at $110^{\circ} \mathrm{C}$ for 24 h (Gehrke et al., 1985; Nagel and Broderick, 1992). Hydrolysates were evaporated to moistness using a concentrator (SpeedVac Concentrator SVC-200H, Savant Instruments, Inc., Farmingdale, NY), redissolved in $1 \mathrm{~mL}$ of distilled water, evaporated again, dissolved in $1 \mathrm{~mL}$ of $\mathrm{pH} 2.2$ sodium citrate buffer (Na-S, Beckman Instruments, Inc., Palo Alto, CA), and analyzed for individual AA by ion-exchange chromatography as described earlier. The 5-mL filtrates saved for FAA analysis were evaporated to moistness and dissolved in $2 \mathrm{~mL}$ of $\mathrm{pH} 2.2$ sodium citrate buffer. An attempt was made to analyze FAA on this nonhydrolyzed sample containing peptide- and protein-bound AA. However, ammonia and peptide-bound AA appeared to saturate the binding sites of the ion-exchange column, hindering chromatographic separation. Therefore, 1 $\mathrm{mL}$ of $2 M \mathrm{~K}_{2} \mathrm{CO}_{3}$ was added to $1 \mathrm{~mL}$ of evaporated and buffer-dissolved sample, heated at $60^{\circ} \mathrm{C}$ for $24 \mathrm{~h}$ to volatilize ammonia, the $\mathrm{pH}$ adjusted to 2.2 by adding $2 \mathrm{~mL}$ of $0.16 \mathrm{M}$ sodium citrate and $2.2 \mathrm{M} \mathrm{HCl}$, and filtered through a $3-\mathrm{kDa}$ MW cut-off ultracentrifugation filter before analysis of individual AA by ion-exchange chromatography as described earlier. The concentration of homoarginine in each of the 4 soluble $\mathrm{N}$ fractions was used to compute the content of each AA in its free form in the $10 \mathrm{~K}, 3-10 \mathrm{~K}$, and small peptide fractions as follows:

\section{$\mathrm{AA}_{\mathrm{i}}$ from $\mathrm{FAA}$ in bound $\mathrm{AA}$ fraction = $\left(\mathrm{AA}_{\mathrm{i}}\right.$ in $\mathrm{FAA} / \mathrm{HArg}$ in $\left.\mathrm{FAA}\right)$ $\times$ HArg in bound AA fraction}

where bound AA fraction is either $10 \mathrm{~K}, 3-10 \mathrm{~K}$, or small peptide.

Free AA remaining in bound AA fractions were subtracted from those fractions and added to the FAA fraction. Remaining retentates from the $10-\mathrm{kDa}$ membrane and both retentates and filtrates from the 3$\mathrm{kDa}$ membranes were thawed and an equal volume of $2 \mathrm{M} \mathrm{K}_{2} \mathrm{CO}_{3}$ was added. Samples were evaporated using a SpeedVac concentrator to a volume of approximately $200 \mu \mathrm{L}$. Concentrated samples were transferred to tin cups $(5 \times 9 \mathrm{~mm}$; Costech Analytical Technologies, Valencia, CA) and placed in a $60^{\circ} \mathrm{C}$ oven for $24 \mathrm{~h}$ to volatilize ammonia. Samples were analyzed for ${ }^{15} \mathrm{~N}$ enrichment by isotope ratio mass spectrometry as described earlier. The ${ }^{15} \mathrm{~N}$ enrichments of FAB and PAB and of each soluble $\mathrm{N}$ fraction were used to calculate the proportion of soluble $\mathrm{N}$ of microbial origin in each fraction.

\section{Statistical Analyses}

Data were analyzed using PROC MIXED in SAS (SAS Institute, 1999). The following model was fitted to all variables that did not have repeated measurements over time:

$$
\mathrm{Y}_{\mathrm{jkl}}=\mu+\mathrm{P}_{\mathrm{j}}+\mathrm{C}_{\mathrm{k}}+\mathrm{T}_{\mathrm{l}}+\varepsilon_{\mathrm{jkl}},
$$

where $Y_{j k l}$ is the dependent variable, $\mu$ is the overall mean, $P_{j}$ is the effect of period $j, C_{k}$ is the effect of cow $\mathrm{k}, \mathrm{T}_{\mathrm{l}}$ is the effect of treatment $\mathrm{l}$, and $\varepsilon_{\mathrm{jkl}}$ is the residual error. The degrees of freedom for treatment were partitioned into 3 single-degree-of-freedom orthogonal contrasts: urea vs. true protein (urea vs. CGM), high vs. low predicted protein degradability (SSBM vs. XSBM), and soybean vs. corn protein (XSBM vs. CGM). All terms were considered fixed except for $\mathrm{C}_{\mathrm{k}}$, which was considered random. 
The following model was used for ruminal variables for which there were repeated measurements over time ( $\mathrm{pH}, \mathrm{NH}_{3}$, and total FAA):

$$
\mathrm{Y}_{\mathrm{jklm}}=\mu+\mathrm{P}_{\mathrm{j}}+\mathrm{C}_{\mathrm{k}}+\mathrm{T}_{1}+\varepsilon_{\mathrm{jkl}}+\mathrm{Z}_{\mathrm{m}}+\mathrm{ZT}_{\mathrm{ml}}+\omega_{\mathrm{jklm}}
$$

where $Y_{j k l m}$ is the dependent variable, $\mu$ is the overall mean, $P_{j}$ is the effect of period $j, C_{k}$ is the effect of cow $\mathrm{k}, \mathrm{T}_{1}$ is the effect of treatment $\mathrm{l}, \varepsilon_{\mathrm{jkl}}$ is the whole plot error, $\mathrm{Z}_{\mathrm{m}}$ is the effect of time $\mathrm{m}, \mathrm{ZT}_{\mathrm{ml}}$ is the interaction between time $\mathrm{m}$ and treatment $\mathrm{l}$, and $\omega_{\mathrm{jklm}}$ is the subplot error. Based on the largest value for Akaike's information criterion (Littell et al., 1996), the heterogeneous autoregressive structure ARH(1) was selected as the appropriate covariance structure. The subject of the repeated measurements was defined as cow (square $\times$ period $\times$ treatment). All terms were considered fixed, except for $\mathrm{C}_{\mathrm{k}}$, which was considered random. Because the $\mathrm{ZT}_{\mathrm{ml}}$ interaction was not significant at $a=0.05$ for any of the ruminal variables measured, treatment means were compared across sampling times using the contrasts described above. Differences between least squares means were considered significant at $P<0.05$, and differences were considered to indicate a trend toward significance at $0.05<P<0.10$.

\section{RESULTS AND DISCUSSION}

\section{Diet Composition, Animal Production, and Ruminal Digestion}

Diets were formulated to be isoenergetic (mean = $1.58 \mathrm{Mcal} / \mathrm{kg}$ of $\mathrm{NE}_{\mathrm{L}}$ ) and to provide 2 levels of $\mathrm{CP}$ : high (19.7 and $18.2 \%$ for diets A and D) and low (15.8 and $15.3 \%$ for diets B and C; Table 1). Within each CP level, diets differed in the $\mathrm{N}$ form (urea vs. true protein for diets $\mathrm{A}$ and $\mathrm{D}$ ), the predicted ruminal degradability of the soybean protein (nontreated vs. treated SBM for diets B and C), and the source of the protein (soybean vs. corn for diets $\mathrm{C}$ and $\mathrm{D}$ ). Dietary concentrations (\% of dietary $\mathrm{DM}$ ) of $\mathrm{NDF}, \mathrm{ADF}$, starch, and $\mathrm{NFC}$ ranged from 28.1 to $31.8 \%$, from 17.5 to $20 \%$, from 26.1 to $28.1 \%$, and from 41.2 to $45.5 \%$, respectively. Diets differed substantially in the proportion of the total $\mathrm{N}$ in $\mathrm{AA}$, with diet $\mathrm{D}$ being highest (82.3\%), diets $\mathrm{B}$ and $\mathrm{C}$ intermediate (68.8 and $64.4 \%$, respectively), and diet A the lowest (35.5\%). The chemical composition of the silages and concentrate mixes is presented in Table 2.

Because of the small number of experimental units, the milk production and composition data reported herein are least squares means averaged across diets. Yields of milk, milk fat, and milk true protein averaged $31.2,1.39$, and $0.91 \mathrm{~kg} / \mathrm{d}$ across diets. Concentrations of fat, true protein, and urea $\mathrm{N}$ in milk averaged $4.49 \%$, $2.98 \%$, and $10.6 \mathrm{mg} / \mathrm{dL}$ across diets.
When fed high-CP diets, cows whose diets were supplemented with urea had similar DMI, ruminal $\mathrm{pH}$, and FAA concentrations but a higher ruminal ammonia concentration (Table 3 ) than cows whose diets were supplemented with CGM. Previous reports indicate that intakes of DM by lactating cows fed diets supplemented with urea were depressed, either significantly (Reynal and Broderick, 2003) or not significantly (Wohlt et al., 1991), by $2 \mathrm{~kg} / \mathrm{d}$ compared with cows whose diets were supplemented with CGM. However, urea-supplemented diets contained less CP than did CGM diets, confounding the effects of source and level of dietary protein (Wohlt et al., 1991; Reynal and Broderick, 2003). Within the low-CP diets, there was no difference between SSBM and XSBM on DMI or any of the ruminal variables measured. Replacing XSBM with CGM resulted in a significant decrease in DMI and ruminal FAA concentration. These results are in agreement with data from a meta-analytic review of the literature (Ipharraguerre and Clark, 2005) showing that the replacement of SSBM with corn by-products frequently depresses DMI by lactating dairy cows. It should be noted, however, that in this study the effects of dietary protein source (soybean vs. corn) and concentration ( 15.3 vs. $18.2 \% \mathrm{CP}$ ) are confounded. Within CP level, neither urea vs. true protein nor SSBM vs. XSBM had significant effects on omasal flows and ruminal digestibilities of DM and OM (Table 3). Higher DMI for cows fed XSBM resulted in higher flows of DM and OM at the omasal canal, compared with cows fed CGM. However, apparent ruminal digestibility of $\mathrm{DM}$ and true ruminal $\mathrm{OM}$ digestibility were not affected by dietary treatment. As expected, cows fed diets supplemented with urea had smaller flows of total NAN and nonammonia nonmicrobial N (NANMN) at the omasal canal but a higher true ruminal digestibility of $\mathrm{N}$ than cows fed CGM (Table 4). Cows fed XSBM had a greater flow of NANMN (222 vs. $177 \mathrm{~g}$ of N/d) but a similar flow of microbial NAN compared with cows fed SSBM, resulting in a trend $(P<0.09)$ for a greater flow of NAN. Previous work showed similar changes in the ruminal outflow of $\mathrm{N}$ fractions when SSBM was replaced with XSBM (Ipharraguerre et al., 2005) and other rumen-protected soy products (Ipharraguerre and Clark, 2005). Replacing XSBM with CGM depressed the omasal flows of total NAN (from 622 to $538 \mathrm{~g} / \mathrm{d}$ ) and NANMN (from 222 to $163 \mathrm{~g} / \mathrm{d}$ ), at least in part because of the associated effects on DMI. Microbial efficiencies were not significantly affected by dietary treatments (Table 4).

As expected from the AA concentrations of the concentrate mixes (Table 2), the intakes of all AA, except Lys, were significantly higher for cows fed CGM compared with urea, and intakes of individual AA were 
Table 2. Nutrient composition of silages and concentrate mixes ${ }^{1}$

\begin{tabular}{|c|c|c|c|c|c|c|}
\hline Item $^{2}$ & $\begin{array}{l}\text { Alfalfa } \\
\text { silage }\end{array}$ & $\begin{array}{l}\text { Corn } \\
\text { silage }\end{array}$ & $\begin{array}{l}\text { Urea } \\
\text { mix }\end{array}$ & $\begin{array}{l}\text { SSBM } \\
\text { mix }\end{array}$ & $\begin{array}{l}\text { XSBM } \\
\operatorname{mix}\end{array}$ & $\begin{array}{l}\text { CGM } \\
\text { mix }\end{array}$ \\
\hline $\mathrm{OM}, \%$ of $\mathrm{DM}$ & 88.0 & 95.0 & 90.3 & 89.6 & 89.6 & 91.1 \\
\hline $\mathrm{CP}, \%$ of $\mathrm{DM}$ & 22.5 & 8.8 & 29.3 & 16.8 & 17.1 & 26.0 \\
\hline $\mathrm{NDF}, \%$ of DM & 39.0 & 33.5 & 9.0 & 9.0 & 12.4 & 6.6 \\
\hline $\mathrm{ADF}, \%$ of $\mathrm{DM}$ & 30.0 & 18.7 & 2.1 & 2.9 & 3.4 & 1.7 \\
\hline Starch, \% of DM & 0.46 & 31.6 & 45.2 & 42.4 & 40.8 & 33.7 \\
\hline TAAN, \% of TN & 51.2 & 55.5 & 20.6 & 93.8 & 77.0 & 100.0 \\
\hline $\mathrm{NPN}, \%$ of TN & 48.8 & 44.5 & 79.4 & 6.2 & 23.0 & 0.0 \\
\hline \multicolumn{7}{|l|}{$\mathrm{AA}, \%$ of total AA } \\
\hline \multicolumn{7}{|l|}{ Essential } \\
\hline Arg & 2.29 & 2.56 & 5.42 & 5.87 & 6.10 & 3.19 \\
\hline His & 1.85 & 1.97 & 2.52 & 2.46 & 2.49 & 1.78 \\
\hline Ile & 4.67 & 4.39 & 2.77 & 3.29 & 3.55 & 2.89 \\
\hline Leu & 8.24 & 11.2 & 10.7 & 8.47 & 8.93 & 14.5 \\
\hline Lys & 4.89 & 2.87 & 3.21 & 5.39 & 4.32 & 1.73 \\
\hline Met & 1.36 & 1.65 & 1.72 & 1.30 & 1.37 & 1.93 \\
\hline Phe & 5.07 & 4.02 & 4.17 & 4.57 & 4.43 & 4.96 \\
\hline Thr & 5.08 & 4.86 & 3.99 & 3.99 & 4.21 & 3.40 \\
\hline Val & 6.17 & 6.23 & 3.94 & 4.00 & 3.87 & 3.85 \\
\hline \multicolumn{7}{|l|}{ Nonessential } \\
\hline Ala & 8.57 & 12.6 & 7.19 & 5.03 & 5.43 & 8.35 \\
\hline Asp & 17.4 & 7.41 & 8.02 & 11.0 & 10.8 & 6.34 \\
\hline Cys & 1.56 & 2.06 & 3.49 & 2.73 & 2.56 & 2.64 \\
\hline Glu & 10.5 & 16.6 & 19.8 & 21.4 & 20.9 & 23.3 \\
\hline Gly & 5.47 & 5.68 & 4.63 & 4.09 & 4.61 & 2.92 \\
\hline Pro & 7.45 & 8.48 & 8.87 & 7.25 & 6.88 & 8.23 \\
\hline Ser & 5.62 & 4.03 & 5.34 & 5.51 & 5.60 & 5.31 \\
\hline Tyr & 3.86 & 3.33 & 4.27 & 3.58 & 3.91 & 4.67 \\
\hline
\end{tabular}

${ }^{1} \mathrm{SSBM}=$ solvent soybean meal; XSBM = xylose-treated soybean meal; CGM = corn gluten meal.

${ }^{2}$ TAAN = total AA-N (total $\mathrm{N}$ determined as $\mathrm{N}$ in $17 \mathrm{AA}$ in protein from acid hydrolysates of each silage and concentrate mix); NPN $=$ total $\mathrm{N}-$ total AA-N.

not significantly different for cows fed the SSBM and XSBM diets (Table 5). Although cows fed CGM consumed $4.5 \mathrm{~kg}$ less DM than cows fed XSBM, the higher total AA concentration in the CGM diet (82.3 vs. $64.4 \%$ of total N; Table 1) resulted in intakes of Leu, Met, Phe, Ala, Cys, Glu, Pro, and Tyr that were significantly higher than those for cows fed XSBM (Table 5). Con- versely, the higher Lys content in soybean meal (Table 2) and the greater DMI of cows fed XSBM resulted in a higher Lys intake for cows fed XSBM compared with those fed CGM.

Except for Arg, His, Lys, Met, Thr, Val, and Gly, omasal flows of individual and total AA were significantly higher for cows fed CGM compared with urea

Table 3. Effect of dietary treatment on DMI, milk production, ruminal metabolism, omasal flows, and ruminal digestibilities

\begin{tabular}{|c|c|c|c|c|c|c|c|c|}
\hline \multirow[b]{3}{*}{ Item } & \multicolumn{4}{|c|}{$\operatorname{Diet}^{1}$} & \multirow[b]{3}{*}{ SEM } & \multirow{2}{*}{\multicolumn{3}{|c|}{ Contrast ( $P$-value $)$}} \\
\hline & \multirow{2}{*}{$\begin{array}{l}\text { A } \\
\text { (urea) }\end{array}$} & \multirow{2}{*}{$\begin{array}{l}\text { B } \\
\text { (SSBM) }\end{array}$} & \multirow{2}{*}{$\begin{array}{l}\mathrm{C} \\
(\mathrm{XSBM})\end{array}$} & \multirow{2}{*}{$\begin{array}{l}\mathrm{D} \\
(\mathrm{CGM})\end{array}$} & & & & \\
\hline & & & & & & A vs. D & B vs. C & C vs. D \\
\hline DM intake, kg/d & 18.1 & 20.3 & 22.5 & 18.0 & 2.2 & 0.93 & 0.16 & 0.03 \\
\hline \multicolumn{9}{|l|}{ Rumen } \\
\hline $\mathrm{pH}$ & 6.06 & 6.27 & 6.07 & 6.15 & 0.14 & 0.58 & 0.20 & 0.62 \\
\hline Free AA, mM & 2.76 & 3.36 & 3.79 & 2.53 & 0.29 & 0.56 & 0.25 & $<0.01$ \\
\hline $\mathrm{NH}_{3}-\mathrm{N}, \mathrm{mg} / \mathrm{dL}$ & 22.2 & 13.3 & 10.6 & 12.3 & 1.4 & $<0.01$ & 0.14 & 0.35 \\
\hline \multicolumn{9}{|c|}{ Flow at the omasal canal, $\mathrm{kg} / \mathrm{d}$} \\
\hline $\mathrm{DM}$ & 11.3 & 13.8 & 14.0 & 11.6 & 1.1 & 0.53 & 0.66 & $<0.01$ \\
\hline $\mathrm{OM}$ & 8.97 & 11.27 & 11.28 & 9.11 & 0.91 & 0.72 & 0.97 & $<0.01$ \\
\hline \multicolumn{9}{|c|}{ Ruminal digestibility, \% } \\
\hline DM, apparent & 37.9 & 30.3 & 38.2 & 33.6 & 3.4 & 0.40 & 0.17 & 0.38 \\
\hline OM, true & 60.7 & 53.6 & 59.2 & 59.0 & 1.9 & 0.57 & 0.12 & 0.93 \\
\hline
\end{tabular}

${ }^{1} \mathrm{SSBM}=$ solvent soybean meal; XSBM = xylose-treated soybean meal; CGM = corn gluten meal. 
Table 4. Effect of dietary treatment on intake, flow at the omasal canal, and ruminal digestibility of $\mathrm{N}$ fractions

\begin{tabular}{|c|c|c|c|c|c|c|c|c|}
\hline \multirow[b]{3}{*}{ Item $^{1}$} & \multicolumn{4}{|c|}{ Diet $^{2}$} & \multirow[b]{3}{*}{ SEM } & \multirow{2}{*}{\multicolumn{3}{|c|}{ Contrast ( $P$-value $)$}} \\
\hline & \multirow{2}{*}{$\begin{array}{l}\text { A } \\
\text { (urea) }\end{array}$} & \multirow{2}{*}{$\begin{array}{l}\text { B } \\
(\mathrm{SSBM})\end{array}$} & \multirow{2}{*}{$\begin{array}{l}\mathrm{C} \\
(\mathrm{XSBM})\end{array}$} & \multirow{2}{*}{$\begin{array}{l}\mathrm{D} \\
(\mathrm{CGM})\end{array}$} & & & & \\
\hline & & & & & & A vs. D & B vs. C & C vs. D \\
\hline Total N intake, g/d & 575 & 500 & 572 & 519 & 63 & 0.24 & 0.15 & 0.25 \\
\hline Omasal flows, $\mathrm{g} / \mathrm{d}$ & & & & & & & & \\
\hline Total NAN & 456 & 567 & 622 & 538 & 36 & 0.03 & 0.09 & 0.03 \\
\hline LAB-NAN & 102 & 132 & 134 & 120 & 7 & 0.17 & 0.84 & 0.25 \\
\hline PAB-NAN & 259 & 258 & 266 & 255 & 26 & 0.90 & 0.75 & 0.68 \\
\hline Total microbial NAN & 361 & 389 & 400 & 375 & 28 & 0.57 & 0.66 & 0.34 \\
\hline NANMN & 95 & 177 & 222 & 163 & 14 & $<0.01$ & 0.01 & $<0.01$ \\
\hline Microbial efficiency, g/kg & 35.8 & 40.5 & 32.9 & 40.1 & 3.5 & 0.36 & 0.15 & 0.17 \\
\hline True ruminal $\mathrm{N}$ digestibility, \% & 84.3 & 63.7 & 60.3 & 66.0 & 4.9 & 0.03 & 0.59 & 0.84 \\
\hline
\end{tabular}

\footnotetext{
${ }^{1}$ LAB-NAN = liquid-associated bacteria NAN, microbial efficiency $=\mathrm{g}$ of microbial NAN/kg of OM truly digested in the rumen; PAB-NAN = particle-associated bacteria NAN; NANMN = nonammonia nonmicrobial N.

${ }^{2} \mathrm{SSBM}=$ solvent soybean meal; XSBM = xylose-treated soybean meal; CGM = corn gluten meal.
}

(Table 6). Replacing SSBM with XSBM resulted in a significant increase in the flows of Phe, Glu, and Ser, and a trend for a significant increase in total AA flow $(P=0.10)$, which is in general agreement with data reported elsewhere (Ipharraguerre and Clark, 2005; Ipharraguerre et al., 2005). In the present trial, flows of Arg, Ile, and Lys were significantly reduced when XSBM was replaced with CGM in the diets. Similarly, replacement of SSBM with CGM significantly reduced the flow of Lys to the intestines of cows fed a corn silage-based diet (Klusmeyer et al., 1990). However, when compared with XSBM, the higher intake of Leu by cows fed CGM (457 vs. $252 \mathrm{~g}$ of AA/d; Table 5) resulted in a significantly higher omasal flow of this essential AA (265 vs. $241 \mathrm{~g}$ of AA/d; Table 6).

There were no dietary effects on flows of individual AA of microbial origin (Table 7). However, flows of AA of dietary origin were significantly affected by diets (Table 8). Cows fed diets supplemented with urea had significantly lower flows of 3 essential AA (Leu, Phe, and Val), 6 nonessential AA (Ala, Cys, Glu, Pro, Ser, and Tyr), and total AA of dietary origin, compared with cows fed CGM diets. The flow of Leu was significantly higher for cows fed CGM, compared with those fed

Table 5. Effect of dietary treatment on intake of AA (g/d)

\begin{tabular}{|c|c|c|c|c|c|c|c|c|}
\hline \multirow[b]{3}{*}{ AA } & \multicolumn{4}{|c|}{$\operatorname{Diet}^{1}$} & \multirow[b]{3}{*}{ SEM } & \multirow{2}{*}{\multicolumn{3}{|c|}{ Contrast ( $P$-value $)$}} \\
\hline & \multirow{2}{*}{$\begin{array}{l}\text { A } \\
\text { (urea) }\end{array}$} & \multirow{2}{*}{$\begin{array}{l}\text { B } \\
(\mathrm{SSBM})\end{array}$} & \multirow{2}{*}{$\begin{array}{l}\mathrm{C} \\
(\mathrm{XSBM})\end{array}$} & \multirow{2}{*}{$\begin{array}{l}\mathrm{D} \\
(\mathrm{CGM})\end{array}$} & & & & \\
\hline & & & & & & A vs. D & B vs. C & C vs. D \\
\hline \multicolumn{9}{|c|}{ Essential } \\
\hline Arg & 55 & 118 & 116 & 103 & 11.8 & 0.01 & 0.9 & 0.26 \\
\hline His & 33.8 & 59.5 & 59.8 & 63.5 & 6.6 & $<0.01$ & 0.94 & 0.5 \\
\hline Ile & 63 & 102 & 109 & 119 & 12 & $<0.01$ & 0.5 & 0.36 \\
\hline Leu & 160 & 229 & 252 & 457 & 40 & $<0.01$ & 0.58 & 0.01 \\
\hline Lys & 61 & 132 & 113 & 85 & 11.5 & 0.07 & 0.13 & 0.05 \\
\hline Met & 25.2 & 35.8 & 39.1 & 63.3 & 5.6 & $<0.01$ & 0.55 & 0.02 \\
\hline Phe & 73 & 121 & 123 & 171 & 16 & $<0.01$ & 0.88 & 0.04 \\
\hline Thr & 74 & 118 & 124 & 136 & 13 & $<0.01$ & 0.58 & 0.34 \\
\hline Val & 86 & 131 & 135 & 159 & 15 & $<0.01$ & 0.76 & 0.13 \\
\hline \multicolumn{9}{|c|}{ Nonessential } \\
\hline Ala & 146 & 188 & 210 & 311 & 28 & $<0.01$ & 0.41 & 0.02 \\
\hline Asp & 188 & 328 & 329 & 298 & 34 & 0.02 & 0.96 & 0.3 \\
\hline Cys & 37.8 & 61.0 & 59.4 & 83.5 & 7.8 & $<0.01$ & 0.81 & 0.03 \\
\hline Glu & 249 & 465 & 465 & 711 & 65 & $<0.01$ & 0.99 & 0.03 \\
\hline Gly & 83.1 & 126.5 & 136.7 & 129.8 & 13.9 & 0.02 & 0.36 & 0.5 \\
\hline Pro & 132 & 198 & 201 & 285 & 26 & $<0.01$ & 0.9 & 0.03 \\
\hline Ser & 83.3 & 140.3 & 144.8 & 183.8 & 18.0 & $<0.01$ & 0.78 & 0.07 \\
\hline Tyr & 62.7 & 94.7 & 103.9 & 153.9 & 14.1 & $<0.01$ & 0.5 & 0.03 \\
\hline Total & 1,616 & 2,649 & 2,724 & 3,516 & 334 & 0.01 & 0.83 & 0.09 \\
\hline
\end{tabular}

${ }^{1} \mathrm{SSBM}=$ solvent soybean meal; XSBM = xylose-treated soybean meal; CGM = corn gluten meal. 
Table 6. Effect of dietary treatments on flows of individual AA (g/d) at the omasal canal

\begin{tabular}{|c|c|c|c|c|c|c|c|c|}
\hline \multirow[b]{3}{*}{ AA } & \multicolumn{4}{|c|}{ Diet $^{1}$} & \multirow[b]{3}{*}{ SEM } & \multirow{2}{*}{\multicolumn{3}{|c|}{ Contrast ( $P$-value $)$}} \\
\hline & \multirow{2}{*}{$\begin{array}{l}\text { A } \\
\text { (urea) }\end{array}$} & \multirow{2}{*}{$\begin{array}{l}\text { B } \\
\text { (SSBM) }\end{array}$} & \multirow{2}{*}{$\begin{array}{l}\mathrm{C} \\
(\mathrm{XSBM})\end{array}$} & \multirow{2}{*}{$\begin{array}{l}\text { D } \\
(\mathrm{CGM})\end{array}$} & & & & \\
\hline & & & & & & A vs. D & B vs. $\mathrm{C}$ & C vs. D \\
\hline \multicolumn{9}{|c|}{ Essential } \\
\hline Arg & 84 & 124 & 136 & 107 & 9 & 0.10 & 0.18 & 0.04 \\
\hline His & 29.4 & 47.6 & 48.4 & 36.4 & 4.1 & 0.32 & 0.95 & 0.14 \\
\hline Ile & 96 & 126 & 131 & 112 & 9 & 0.03 & 0.24 & 0.02 \\
\hline Leu & 178 & 225 & 241 & 265 & 16 & $<0.01$ & 0.11 & 0.05 \\
\hline Lys & 113 & 152 & 150 & 114 & 8 & 0.83 & 0.75 & $<0.01$ \\
\hline Met & 60.1 & 71.3 & 78.1 & 70.8 & 13.3 & 0.65 & 0.76 & 0.68 \\
\hline Phe & 99 & 123 & 144 & 137 & 11 & $<0.01$ & 0.03 & 0.27 \\
\hline Thr & 106 & 136 & 145 & 125 & 9 & 0.1 & 0.37 & 0.09 \\
\hline Val & 93 & 120 & 129 & 114 & 9 & 0.06 & 0.27 & 0.12 \\
\hline \multicolumn{9}{|c|}{ Nonessential } \\
\hline Ala & 143 & 180 & 186 & 190 & 11 & $<0.01$ & 0.48 & 0.65 \\
\hline Asp & 234 & 316 & 348 & 277 & 20 & 0.03 & 0.07 & $<0.01$ \\
\hline Cys & 39.5 & 49.0 & 52.9 & 50.5 & 3.2 & $<0.01$ & 0.11 & 0.27 \\
\hline Glu & 309 & 414 & 476 & 452 & 26 & $<0.01$ & 0.01 & 0.13 \\
\hline Gly & 109 & 140 & 150 & 125 & 9 & 0.09 & 0.23 & 0.03 \\
\hline Pro & 94 & 122 & 131 & 141 & 7 & $<0.01$ & 0.07 & 0.09 \\
\hline Ser & 101 & 134 & 146 & 134 & 8 & $<0.01$ & 0.03 & 0.03 \\
\hline Tyr & 97 & 126 & 131 & 126 & 8 & 0.01 & 0.43 & 0.43 \\
\hline Total & 1,985 & 2,604 & 2,822 & 2,576 & 158 & 0.04 & 0.08 & 0.10 \\
\hline
\end{tabular}

${ }^{1} \mathrm{SSBM}=$ solvent soybean meal; XSBM = xylose-treated soybean meal; CGM = corn gluten meal.

XSBM. Replacement of SSBM with XSBM did not affect the flows of individual AA of dietary origin.

\section{Soluble NAN Fractionation and Analysis: Methodological Considerations}

Despite the potential benefits of small peptides on ruminant nutrition, most studies on digestion and me- tabolism of peptides have relied on techniques that may result in biased estimates of peptide concentration. Most commonly, samples are first chemically deproteinized by acid precipitation, and peptide concentration in the supernatant is measured by the "difference" method, in which peptide AA are calculated as the difference between total AA in hydrolyzed supernatant minus free AA before hydrolysis. However,

Table 7. Effect of dietary treatments on flows of microbial AA (g/d) at the omasal canal

\begin{tabular}{|c|c|c|c|c|c|c|c|c|}
\hline \multirow[b]{3}{*}{$\mathrm{AA}$} & \multicolumn{4}{|c|}{$\operatorname{Diet}^{1}$} & \multirow[b]{3}{*}{ SEM } & \multirow{2}{*}{\multicolumn{3}{|c|}{ Contrast ( $P$-value $)$}} \\
\hline & \multirow{2}{*}{$\begin{array}{l}\text { A } \\
\text { (urea) }\end{array}$} & \multirow{2}{*}{$\begin{array}{l}\text { B } \\
(\mathrm{SSBM})\end{array}$} & \multirow{2}{*}{$\begin{array}{l}\mathrm{C} \\
(\mathrm{XSBM})\end{array}$} & \multirow{2}{*}{$\begin{array}{l}\mathrm{D} \\
(\mathrm{CGM})\end{array}$} & & & & \\
\hline & & & & & & A vs. D & B vs. C & C vs. D \\
\hline \multicolumn{9}{|c|}{ Essential } \\
\hline Arg & 74.4 & 98.3 & 94.6 & 89.8 & 6.6 & 0.17 & 0.59 & 0.50 \\
\hline His & 27.7 & 31.5 & 29.9 & 27.1 & 3.6 & 0.90 & 0.75 & 0.56 \\
\hline Ile & 84.6 & 96.4 & 96.4 & 85.9 & 10.4 & 0.93 & 0.99 & 0.48 \\
\hline Leu & 137 & 155 & 158 & 141 & 14 & 0.79 & 0.85 & 0.38 \\
\hline Lys & 103 & 131 & 136 & 106 & 11 & 0.84 & 0.75 & 0.14 \\
\hline Met & 42.0 & 45.9 & 56.2 & 60.2 & 12.6 & 0.47 & 0.65 & 0.82 \\
\hline Phe & 81.1 & 96.8 & 96.9 & 87.9 & 8.5 & 0.57 & 0.99 & 0.46 \\
\hline Thr & 94.5 & 108.8 & 110.9 & 99.0 & 8.9 & 0.73 & 0.87 & 0.38 \\
\hline Val & 86.8 & 100.7 & 102.0 & 90.2 & 9.0 & 0.78 & 0.91 & 0.36 \\
\hline \multicolumn{9}{|c|}{ Nonessential } \\
\hline Ala & 129 & 148 & 150 & 133 & 11 & 0.76 & 0.89 & 0.30 \\
\hline Asp & 205 & 268 & 257 & 215 & 24 & 0.79 & 0.77 & 0.31 \\
\hline Cys & 27.4 & 31.6 & 31.8 & 28.1 & 2.6 & 0.85 & 0.95 & 0.40 \\
\hline Glu & 248 & 287 & 291 & 259 & 23 & 0.75 & 0.91 & 0.36 \\
\hline Gly & 95.3 & 109.1 & 110.8 & 98.9 & 8.6 & 0.75 & 0.88 & 0.34 \\
\hline Pro & 65.5 & 73.4 & 74.9 & 67.5 & 6.1 & 0.81 & 0.86 & 0.40 \\
\hline Ser & 80.0 & 91.8 & 94.2 & 83.0 & 7.5 & 0.77 & 0.82 & 0.32 \\
\hline Tyr & 86.3 & 100.5 & 99.1 & 89.4 & 8.4 & 0.78 & 0.90 & 0.41 \\
\hline Total & 1,668 & 1,974 & 1,990 & 1,762 & 125 & 0.25 & 0.93 & 0.27 \\
\hline
\end{tabular}

${ }^{1} \mathrm{SSBM}=$ solvent soybean meal; XSBM = xylose-treated soybean meal; CGM = corn gluten meal . 
REYNAL ET AL.

Table 8. Effect of dietary treatments on flows of nonammonia nonmicrobial AA (g/d) at the omasal canal

\begin{tabular}{|c|c|c|c|c|c|c|c|c|}
\hline \multirow[b]{3}{*}{$\mathrm{AA}$} & \multicolumn{4}{|c|}{ Diet $^{1}$} & \multirow[b]{3}{*}{ SEM } & \multirow{2}{*}{\multicolumn{3}{|c|}{ Contrast ( $P$-value $)$}} \\
\hline & \multirow{2}{*}{$\begin{array}{l}\text { A } \\
\text { (urea) }\end{array}$} & \multirow{2}{*}{$\begin{array}{l}\text { B } \\
\text { (SSBM) }\end{array}$} & \multirow{2}{*}{$\begin{array}{l}\mathrm{C} \\
(\mathrm{XSBM})\end{array}$} & \multirow{2}{*}{$\begin{array}{l}\mathrm{D} \\
(\mathrm{CGM})\end{array}$} & & & & \\
\hline & & & & & & A vs. D & B vs. C & C vs. D \\
\hline \multicolumn{9}{|c|}{ Essential } \\
\hline Arg & 9.5 & 26.1 & 39.9 & 18.4 & 7.7 & 0.47 & 0.25 & 0.13 \\
\hline His & 1.7 & 16.4 & 18.4 & 9.3 & 5.0 & 0.37 & 0.80 & 0.30 \\
\hline Ile & 12.2 & 29.2 & 35.0 & 26.3 & 6.8 & 0.25 & 0.60 & 0.45 \\
\hline Leu & 42 & 70 & 83 & 123 & 9 & $<0.01$ & 0.31 & 0.03 \\
\hline Lys & 9.9 & 20.9 & 13.8 & 8.0 & 6.5 & 0.85 & 0.50 & 0.58 \\
\hline Met & 19.0 & 22.0 & 22.4 & 11.0 & 11.9 & 0.70 & 0.99 & 0.55 \\
\hline Phe & 18.0 & 25.2 & 47.3 & 48.9 & 6.3 & 0.02 & 0.06 & 0.83 \\
\hline Thr & 11.7 & 27.2 & 33.5 & 25.7 & 4.4 & 0.08 & 0.32 & 0.24 \\
\hline Val & 6.4 & 18.7 & 26.8 & 23.5 & 3.9 & 0.04 & 0.20 & 0.55 \\
\hline \multicolumn{9}{|c|}{ Nonessential } \\
\hline Ala & 14.7 & 31.7 & 35.3 & 56.0 & 5.0 & 0.01 & 0.65 & 0.06 \\
\hline Asp & 28 & 48 & 91 & 61 & 25 & 0.40 & 0.30 & 0.46 \\
\hline Cys & 12.0 & 17.5 & 21.2 & 22.4 & 2.7 & 0.04 & 0.31 & 0.71 \\
\hline Glu & 60 & 127 & 185 & 193 & 22 & 0.02 & 0.14 & 0.80 \\
\hline Gly & 13.8 & 31.2 & 39.2 & 25.8 & 3.5 & 0.08 & 0.18 & 0.06 \\
\hline Pro & 28.6 & 48.5 & 56.9 & 73.2 & 4.7 & $<0.01$ & 0.22 & 0.06 \\
\hline Ser & 21.1 & 42.2 & 52.1 & 51.0 & 6.2 & 0.04 & 0.32 & 0.90 \\
\hline Tyr & 10.5 & 25.2 & 31.4 & 36.2 & 3.9 & 0.02 & 0.34 & 0.45 \\
\hline Total & 319 & 627 & 832 & 814 & 95 & 0.04 & 0.17 & 0.61 \\
\hline
\end{tabular}

${ }^{1} \mathrm{SSBM}=$ solvent soybean meal; XSBM = xylose-treated soybean meal; CGM = corn gluten meal.

agents and conditions used for deproteinization vary substantially among published methodologies. Trichloroacetic, perchloric, and sulfosalicylic acids have been widely used to deproteinize samples of whole blood, blood plasma, and ruminal and intestinal contents. Concentrations of acid, temperatures, and times of incubation have varied. Trichloroacetic acid has been used at a final concentration of $8.3 \%$ (wt/vol) followed by incubation at room temperature for $1 \mathrm{~h}$ (Volden et al., 2002); at 5\% (wt/vol) and samples held on ice for either 30 min (Broderick and Wallace, 1988; Choi et al., 2002a) or overnight (Choi et al., 2002a); and at $10 \%(\mathrm{wt} / \mathrm{vol})$ and samples incubated at $4^{\circ} \mathrm{C}$ for $17 \mathrm{~h}$ (Moughan et al., 1990; Butts et al., 1991). Perchloric acid has been used at $5 \%$ (wt/vol) followed by immediate centrifugation (Chen et al., 1987a; Wallace and McKain, 1990; Backwell et al., 1997), and at 7\% (wt/ vol) followed by incubation at $22^{\circ} \mathrm{C}$ for 10 to $15 \mathrm{~min}$ (Moughan et al., 1990). Finally, deproteinization conditions used with sulfosalicylic acid have been 3.6\% (wt/vol) followed by storage at $-80^{\circ} \mathrm{C}$ (Remond et al., 2000); $2.5 \%$ (wt/vol) at $4^{\circ} \mathrm{C}$ for $16 \mathrm{~h}$ (Galibois et al., 1991); and $4 \%$ (wt/vol) at room temperature for $15 \mathrm{~min}$ (Bernard et al., 2001).

The cut-offs of tungstic and trichloroacetic acids are considered to be approximately at peptide sizes of 3 and $10 \mathrm{AA}$, respectively (Licitra et al., 1996). Assuming an average MW of 127 per AA (based on the average occurrence of individual AA in over 200 proteins; Klapper, 1977), 3 and 10 AA would correspond to average
MW of 381 and 1,270, respectively. However, the extent of deproteinization and the MW of the proteins being precipitated are dependent on the type and concentration of the acid used. Trichloroacetic (10\% wt/ $\mathrm{vol}$ ) and perchloric acids (7\% wt/vol) precipitated, respectively, 26 and $70 \%$ of the total soluble $\mathrm{N}$ in ileal digesta of rats (Butts et al., 1991). Greenberg and Shipe (1979) reported that complete precipitation of $\beta$-LG was achieved at about 15,20 , and $0.5 \%$ (wt/vol) of trichloroacetic, sulfosalicylic, and tungstic acids, respectively. In addition, more than one-half of the soluble $\mathrm{N}$ from ileal digesta of rats remained in solution after deproteinization with perchloric $(7 \% \mathrm{wt} / \mathrm{vol})$ and trichloroacetic acids (10\% wt/vol) with, respectively, 35 and $69 \%$ of the supernatant $\mathrm{N}$ being in the form of soluble protein (Ohara and Ariyoshi, 1979; Moughan et al., 1990). Additionally, the extent of precipitation also depends on protein structure. When TCA was used at $5 \%(\mathrm{wt} / \mathrm{vol})$ to precipitate $\beta$-LG, BSA, keratin, hemoglobulin, myosin, and actomyosin, 12, 0, 14, 4, 1, and $21 \%$ of the protein remained in the supernatant, respectively (Greenberg and Shipe, 1979). Even at a $10 \%$ (wt/vol) concentration of TCA, $11 \%$ of keratin remained in solution (Greenberg and Shipe, 1979). In the study of Bhatty (1972), complete precipitation of soluble proteins from rapeseed meal required a 6 -fold increase in TCA concentration compared with that required to precipitate $\mathrm{CN}$ and hemoglobin. Furthermore, as suggested by Choi et al. (2002a) and Seal and Parker (1998), the use of strong acids may result in 
partial hydrolysis of proteins, release of peptides, and overestimation of the peptide- $\mathrm{N}$ fraction. Therefore, interpretation and comparison of data obtained using these techniques should be done with caution.

Alternatively, soluble $\mathrm{N}$ fractions can be separated using UF with membranes of different MW cut-offs without addition of acids. When filtered through a 10$\mathrm{kDa}$ cut-off membrane, from 88 to $94 \%$ (mean $91 \%$ ) of the $\mathrm{N}$ in purified proteins of MW between 14,300 and $669,000 \mathrm{Da}$ was recovered in the retentate, whereas from 90 to $100 \%$ (mean 95\%) of the $\mathrm{N}$ in peptides between 146 and 6,000 Da was recovered in the filtrate solution (Butts et al., 1991). When peptide concentrations in sheep blood and plasma measured in the filtrate from a $3-\mathrm{kDa}$ cut-off filter were compared with those measured in the supernatant after deproteinization with sulfosalicylic acid, chemical deproteinization overestimated peptide concentrations in blood and plasma samples by 160 and 56\%, respectively (Bernard et al., 2001). Backwell (1998) reported that oligopeptides of MW as high as $9.3 \mathrm{kDa}$ remained in the supernatant after deproteinization of sheep blood samples with sulfosalicylic acid (final concentration of 13\% wt/ vol). When plasma samples from sheep that were deproteinized with sulfosalicylic acid (final acid concentration of $3.3 \% \mathrm{wt} / \mathrm{vol}$ ) were filtered through a $3-\mathrm{kDa}$ cut-off membrane, peptide AA concentrations were less than half of those in deproteinized samples without filtration (Remond et al., 2000). Ultrafiltration has also been used as a pretreatment before separating peptide AA by reverse-phase chromatography (Seal and Parker, 1996). Because UF, alone or followed by chromatographic separation, should not affect the structure and solubility of proteins and peptides, its use may result in more accurate estimates of soluble $\mathrm{N}$ fractions compared with chemical deproteinization. However, the selectivity of the membranes used in UF depends on the size and shape of the proteins and decreases as the MW approaches the cut-off value of the membrane (Butts et al., 1991; Millipore Technical Guide, Millipore Corp.). Moreover, a small proportion of the total volume filtered containing molecules smaller than the MW cut-off will remain in the retentate. Therefore, the MW cut-offs of the membranes are approximate values and some degree of cross-contamination among fractions should be expected. Caution is needed when handling the samples during collection and analysis to avoid protein degradation and contamination. Bacterial and protozoal cells should be immediately removed after sampling to avoid cell lysis and overestimation of soluble $\mathrm{N}$ fractions. Functional proteases and peptidases will result in inaccurate estimates of soluble $\mathrm{N}$ fractions if supernatants are not immediately processed or stored, preferably at $-80^{\circ} \mathrm{C}$, until processed. These are some disadvantages compared with chemical deproteinization, where enzyme activity is immediately stopped by acidification, facilitating sample handling. Nonetheless, immediate highspeed centrifugation followed by freezing in liquid $\mathrm{N}$ should minimize degradation and contamination of soluble $\mathrm{N}$ fractions separated by UF. Therefore, UF of properly processed and stored samples is a preferred method of separating soluble $\mathrm{N}$ fractions than chemical deproteinization.

\section{Omasal Flows of Total AA in Each Soluble N Fraction}

Omasal flows of AA in proteins greater than $10 \mathrm{~K}$ averaged $29 \mathrm{~g} / \mathrm{d}$ across diets $(P>0.10)$, accounting for 1.1 to $1.6 \%$ of total AA flow and from 7 to $13 \%$ of the total soluble AA flow (Table 9). Flows of AA in soluble $3-10 \mathrm{~K}$ oligopeptides averaged $217 \mathrm{~g} / \mathrm{d}$ across diets $(P$ $>0.10$ ) and accounted for 6.4 to $12.5 \%$ of total AA flows at the omasal canal and for most of the soluble AA flow (65 to 79\%; Table 10). Cows supplemented with urea tended $(P=0.09)$ to have lower proportions of soluble AA as $3-10 \mathrm{~K}$ oligopeptides than cows fed true protein from CGM (65.4 vs. $79.3 \%)$. Soluble AA fractions containing bound AA of MW above $3 \mathrm{kDa}$ accounted for 78 to $86 \%$ of the soluble AA flow and 7.5 to $13.6 \%$ of the total AA flow at the omasal canal. On the contrary, soluble protein (defined as NAN in a $10 \%$ TCA precipitate) accounted for only 0.9 to $1.6 \%$ (Choi et al., 2002b), 21 to 23\% (Choi et al., 2003), and 20 to 26\% (Choi et al., 2002a) of the total omasal flow of soluble NAN (SNAN). However, incomplete precipitation of proteins by acid deproteinization might have resulted in underestimation of soluble proteins in these studies.

Flows of small peptides were significantly affected by the protein supplement (Table 11). Cows whose diets were supplemented with SSBM had higher flows of small peptide-AA than those whose diets were supplemented with XSBM (59.6 vs. $45.5 \mathrm{~g}$ of $\mathrm{AA} / \mathrm{d}$ ), whereas supplementation with CGM resulted in higher small peptide-AA flows than did XSBM (49.1 vs. $45.5 \mathrm{~g}$ of $\mathrm{AA} / \mathrm{d}$ ). However, small peptide-AA accounted for only 1.63 to $2.80 \%$ of the total AA flow and 12.7 to $20.3 \%$ of the total soluble AA flow. Similarly, Broderick and Wallace (1988) estimated that between 1.2 and $2.4 \%$ of the ruminal NAN flow in sheep fed ryegrass-based diets was contributed by FAA and peptides, determined by trinitrotrobenzene sulfonic acid and fluorescamine reactions, respectively, on TCA supernatants. However, peptide-AA concentrations in the perchloric acid supernatant of the rumen fluid of sheep assayed by fluorescamine reaction were, on av- 
Table 9. Effect of dietary treatment on omasal canal flows of individual AA (g/d) in soluble proteins of molecular weights greater than $10 \mathrm{kDa}$

\begin{tabular}{|c|c|c|c|c|c|c|c|c|}
\hline \multirow[b]{3}{*}{$\mathrm{AA}^{1}$} & \multicolumn{4}{|c|}{$\operatorname{Diet}^{2}$} & \multirow[b]{3}{*}{ SEM } & \multirow{2}{*}{\multicolumn{3}{|c|}{ Contrast ( $P$-value $)$}} \\
\hline & \multirow{2}{*}{$\begin{array}{l}\text { A } \\
\text { (urea) }\end{array}$} & \multirow{2}{*}{$\begin{array}{l}\text { B } \\
(\mathrm{SSBM})\end{array}$} & \multirow{2}{*}{$\begin{array}{l}\mathrm{C} \\
(\mathrm{XSBM})\end{array}$} & \multirow{2}{*}{$\begin{array}{l}\mathrm{D} \\
(\mathrm{CGM})\end{array}$} & & & & \\
\hline & & & & & & A vs. D & B vs. C & C vs. D \\
\hline \multicolumn{9}{|l|}{ Essential } \\
\hline Arg & 0.96 & 0.87 & 0.90 & 0.72 & 0.19 & 0.32 & 0.91 & 0.4 \\
\hline His & 0.63 & 0.59 & 0.59 & 0.52 & 0.11 & 0.42 & 0.97 & 0.49 \\
\hline Ile & 1.12 & 1.22 & 1.22 & 1.12 & 0.19 & 0.95 & 0.85 & 0.56 \\
\hline Leu & 1.87 & 1.69 & 1.69 & 1.41 & 0.37 & 0.38 & 1 & 0.55 \\
\hline Lys & 2.04 & 1.93 & 2.04 & 1.62 & 0.37 & 0.38 & 0.79 & 0.39 \\
\hline Met & 0.34 & 0.34 & 0.24 & 0.32 & 0.06 & 0.76 & 0.29 & 0.33 \\
\hline Phe & 0.78 & 0.77 & 0.79 & 0.64 & 0.21 & 0.62 & 0.92 & 0.57 \\
\hline Thr & 2.47 & 2.55 & 2.55 & 2.21 & 0.34 & 0.57 & 0.85 & 0.41 \\
\hline Val & 1.84 & 1.84 & 1.84 & 1.50 & 0.33 & 0.4 & 0.95 & 0.43 \\
\hline \multicolumn{9}{|l|}{ Nonessential } \\
\hline $\mathrm{Ala}$ & 2.54 & 2.80 & 2.80 & 2.29 & 0.38 & 0.54 & 0.78 & 0.36 \\
\hline Asp & 4.09 & 4.37 & 4.47 & 3.71 & 0.57 & 0.58 & 0.86 & 0.33 \\
\hline Cys & 0.94 & 0.77 & 0.86 & 0.86 & 0.26 & 0.84 & 0.83 & 0.92 \\
\hline Glu & 4.20 & 4.31 & 4.41 & 3.78 & 0.74 & 0.64 & 0.95 & 0.52 \\
\hline Gly & 1.66 & 1.77 & 1.77 & 1.55 & 0.21 & 0.7 & 0.99 & 0.51 \\
\hline Pro & 1.23 & 1.23 & 1.23 & 1.15 & 0.16 & 0.72 & 0.92 & 0.66 \\
\hline Ser & 1.88 & 1.88 & 1.88 & 1.58 & 0.30 & 0.55 & 0.96 & 0.62 \\
\hline Tyr & 1.28 & 1.36 & 1.33 & 1.13 & 0.21 & 0.55 & 0.92 & 0.45 \\
\hline \multicolumn{9}{|l|}{ Total } \\
\hline $\mathrm{g} / \mathrm{d}$ & 29.9 & 30.3 & 30.6 & 26.1 & 4.8 & 0.53 & 0.95 & 0.48 \\
\hline$\%$ of TSAA flow & 13.2 & 10.0 & 11.0 & 7.0 & 2.4 & 0.13 & 0.74 & 0.27 \\
\hline$\%$ of TAA flow & 1.57 & 1.15 & 1.07 & 1.06 & 0.17 & 0.12 & 0.76 & 0.98 \\
\hline \multicolumn{9}{|l|}{ Microbial } \\
\hline $\mathrm{g} / \mathrm{d}$ & 21.0 & 22.4 & 21.9 & 20.0 & 3.7 & 0.94 & 0.94 & 0.78 \\
\hline$\%$ of total SP flow & 70.2 & 74.1 & 71.5 & 76.6 & 5.8 & 0.46 & 0.75 & 0.55 \\
\hline \multicolumn{9}{|l|}{ Dietary } \\
\hline $\mathrm{g} / \mathrm{d}$ & 8.9 & 7.8 & 8.7 & 6.1 & 2.1 & 0.2 & 0.8 & 0.32 \\
\hline$\%$ of total SP flow & 29.8 & 25.9 & 28.5 & 23.4 & 5.8 & 0.46 & 0.75 & 0.55 \\
\hline
\end{tabular}

${ }^{1} \mathrm{TSAA}=$ total soluble $\mathrm{AA} ; \mathrm{SP}=$ soluble proteins of molecular weight $>10 \mathrm{kDa}$; TAA $=$ total AA.

${ }^{2} \mathrm{SSBM}=$ solvent soybean meal; $\mathrm{XSBM}=$ xylose-treated soybean meal; CGM = corn gluten meal.

erage, $50 \%$ of the concentration determined by ionexchange chromatography of individual peptide-AA in hydrolyzed supernatant (Wallace and McKain, 1990). Therefore, it is possible that the peptide concentrations reported by Broderick and Wallace (1988) were also underestimated by fluorescamine. On the contrary, peptides accounted for an average of 63 (Choi et al., 2002a) and 60\% (Choi et al., 2002b) of the SNAN flowing at the omasal canal, and for an average of $76 \%$ of the soluble $\mathrm{N}$ in ruminal digesta (Chen et al., 1987b). However, as discussed earlier, incomplete acid precipitation of proteins in these studies might have resulted in an overestimation of peptide fractions.

Omasal flows of FAA ranged between 3.73 and 5.68 $\mathrm{g} / \mathrm{d}$ across diets $(P>0.10)$ and accounted for only 0.14 to $0.34 \%$ of the total AA flow and for 1.04 to $1.87 \%$ of the soluble AA flow (Table 12). When measured on solvent-extracted and ultrafiltered (1,000 MW cut-off filter) samples of duodenal digesta, FAA accounted for $0.34 \%$ of the total AA flowing at the duodenum of sheep (Peterson et al., 1971). Similarly, Volden et al. (2001) reported that ruminal outflow of FAA (13.0 to $34.8 \mathrm{~g}$ of $\mathrm{AA} / \mathrm{d}$ ) contributed a small proportion (between 1.3 and $1.8 \%$ ) of the total duodenal AA flow in dairy cows fed grass silage-diets supplemented with proteins of differing ruminal degradabilities. However, omasal FAA-N flow in cows fed grass silage-diets supplemented with barley plus either skimmed-milk powder, wet distillers solubles, or rapeseed meal accounted for between 24 and $44 \%$ of the total SNAN flow (Choi et al., 2002b). In a companion study, Choi et al. (2002a) reported that FAA-N flows in cows fed grass silage diets supplemented with barley, rapeseed meal, or a combination of the two contributed between 11.3 and $13.2 \%$ of total SNAN.

The omasal flows of total soluble AA ranged from 254 to $377 \mathrm{~g} / \mathrm{d}$, and from 9.2 to $15.9 \%$ of total AA flow, but were not significantly affected by dietary treatment (Table 13). Similarly, omasal flows of SNAN in cows fed grass silage-based diets supplemented with barley and proteins of differing degradabilities in 3 experiments contributed between 5.7 and $8.9 \%$ of the total NAN flow (Choi et al., 2002a,b; Choi et al., 2003). 
Table 10. Effect of dietary treatment on omasal canal flows of individual AA (g/d) in soluble oligopeptides of molecular weights between 3 and $10 \mathrm{kDa}$

\begin{tabular}{|c|c|c|c|c|c|c|c|c|}
\hline \multirow[b]{3}{*}{$\mathrm{AA}^{1}$} & \multicolumn{4}{|c|}{$\operatorname{Diet}^{2}$} & \multirow[b]{3}{*}{ SEM } & \multirow{2}{*}{\multicolumn{3}{|c|}{ Contrast ( $P$-value $)$}} \\
\hline & \multirow{2}{*}{$\begin{array}{l}\text { A } \\
\text { (urea) }\end{array}$} & \multirow{2}{*}{$\begin{array}{l}\text { B } \\
(\mathrm{SSBM})\end{array}$} & \multirow{2}{*}{$\begin{array}{l}\mathrm{C} \\
(\mathrm{XSBM})\end{array}$} & \multirow{2}{*}{$\begin{array}{l}\mathrm{D} \\
(\mathrm{CGM})\end{array}$} & & & & \\
\hline & & & & & & A vs. D & B vs. C & C vs. D \\
\hline \multicolumn{9}{|l|}{ Essential } \\
\hline Arg & 4.20 & 4.97 & 4.85 & 8.86 & 1.80 & 0.13 & 0.96 & 0.17 \\
\hline His & 5.54 & 6.50 & 6.21 & 8.46 & 0.63 & 0.05 & 0.77 & 0.09 \\
\hline Ile & 6.74 & 9.09 & 7.31 & 12.93 & 1.78 & 0.1 & 0.55 & 0.12 \\
\hline Leu & 9.37 & 12.08 & 8.52 & 21.26 & 4.87 & 0.15 & 0.6 & 0.13 \\
\hline Lys & 11.8 & 11.7 & 12.1 & 18.2 & 2.6 & 0.17 & 0.92 & 0.18 \\
\hline Met & 2.56 & 3.62 & 2.34 & 4.69 & 1.81 & 0.46 & 0.65 & 0.43 \\
\hline Phe & 3.66 & 7.19 & 6.25 & 7.55 & 1.77 & 0.21 & 0.73 & 0.63 \\
\hline Thr & 10.9 & 11.6 & 10.3 & 17.3 & 2.7 & 0.18 & 0.73 & 0.15 \\
\hline Val & 9.70 & 11.54 & 9.70 & 15.97 & 2.09 & 0.1 & 0.54 & 0.1 \\
\hline \multicolumn{9}{|l|}{ Nonessential } \\
\hline Ala & 13.7 & 20.2 & 14.2 & 24.4 & 4.3 & 0.17 & 0.39 & 0.18 \\
\hline Asp & 23.4 & 26.8 & 27.8 & 37.3 & 5.6 & 0.18 & 0.9 & 0.32 \\
\hline Cys & 6.7 & 17.2 & 11.6 & 15.0 & 3.1 & 0.12 & 0.24 & 0.44 \\
\hline Glu & 25.3 & 27.6 & 25.4 & 43.9 & 8.9 & 0.19 & 0.85 & 0.19 \\
\hline Gly & 13.9 & 16.5 & 15.4 & 20.2 & 1.7 & 0.08 & 0.69 & 0.15 \\
\hline Pro & 9.1 & 10.8 & 10.2 & 16.6 & 2.9 & 0.13 & 0.88 & 0.17 \\
\hline Ser & 8.9 & 9.6 & 8.9 & 15.1 & 2.6 & 0.16 & 0.85 & 0.16 \\
\hline Tyr & 5.69 & 5.69 & 4.53 & 9.57 & 2.07 & 0.23 & 0.71 & 0.16 \\
\hline \multicolumn{9}{|l|}{ Total } \\
\hline $\mathrm{g} / \mathrm{d}$ & 171 & 213 & 186 & 297 & 43 & 0.13 & 0.7 & 0.16 \\
\hline$\%$ of TSAA flow & 65.4 & 67.9 & 69.9 & 79.3 & 3.9 & 0.09 & 0.74 & 0.19 \\
\hline$\%$ of TAA flow & 10.79 & 7.93 & 6.40 & 12.54 & 3.05 & 0.68 & 0.72 & 0.21 \\
\hline \multicolumn{9}{|l|}{ Microbial } \\
\hline $\mathrm{g} / \mathrm{d}$ & 61.1 & 40.2 & 34.7 & 80.8 & 19.2 & 0.33 & 0.78 & 0.21 \\
\hline$\%$ of total OP flow & 35.7 & 18.9 & 18.7 & 27.2 & 5.8 & 0.07 & 0.9 & 0.08 \\
\hline \multicolumn{9}{|l|}{ Dietary } \\
\hline $\mathrm{g} / \mathrm{d}$ & 110.1 & 172.5 & 150.9 & 216.3 & 19.9 & 0.02 & 0.13 & 0.05 \\
\hline$\%$ of total OP flow & 64.3 & 81.1 & 81.3 & 72.8 & 5.8 & 0.07 & 0.9 & 0.08 \\
\hline
\end{tabular}

${ }^{1} \mathrm{TSAA}=$ total soluble $\mathrm{AA} ; \mathrm{TAA}=$ total $\mathrm{AA} ; \mathrm{OP}=$ soluble oligopeptides of molecular weight between 3 and $10 \mathrm{kDa}$.

${ }^{2} \mathrm{SSBM}=$ solvent soybean meal; XSBM = xylose-treated soybean meal; CGM = corn gluten meal.

Soluble bound AA and FAA contributed a substantial proportion (an average of $13 \%$ across diets) of the total AA flowing out of the rumen. However, small peptides accounted for only $2 \%$ of the total AA flow at the omasal canal. This finding suggests that published ruminal concentrations and outflows of peptides might have been overestimated when measured in a chemically deproteinized supernatant.

\section{Omasal Flows of Individual AA Associated with Each Soluble N Fraction}

Only 7 out of 18 AA assayed by ion-exchange chromatography (Arg, His, Ile, Leu, Lys, Phe, and Tyr) were found at detectable concentrations in their free form (Table 12). Concentrations of total FAA (sum of 7) in omasal digesta averaged $26 \mathrm{mg}$ of $\mathrm{AA} / \mathrm{L}$ across diets. Flows of individual AA with soluble proteins greater than $10 \mathrm{~K}$ were not significantly affected by dietary treatment (Table 9). When compared with urea, supplementation with CGM resulted in higher flows of His (8.5 vs. $5.5 \mathrm{~g}$ of $\mathrm{AA} / \mathrm{d})$ and a trend for significantly higher flows of Ile $(P<0.10)$ and Val $(P$ $<0.10)$ associated with soluble oligopeptides of $3-10 \mathrm{~K}$ (Table 10). Cows fed CGM tended $(P<0.10)$ to have higher flows of His and Val in $3-10 \mathrm{~K}$ oligopeptides than cows fed XSBM.

There was no difference between urea and CGM or XSBM and CGM on flows of individual small peptideAA (Table 11). However, flows of Met, Val, Ala, Cys, Gly, and total AA in peptides of less than $3 \mathrm{kDa}$ were significantly higher in cows fed SSBM than XSBM. Yang and Russell (1992) reported that dipeptides containing Pro and either Met, Gly, or Val were degraded by ruminal bacteria in vitro at rates that were more than 2-fold slower than those of dipeptides containing Met, Gly, and Val in combination with AA other than Pro. Although in the present study peptide-bound Pro was not significantly affected by diet, flows of small peptide-bound Met, Gly, Val, and total AA were 460, 25,44 , and $29 \%$ higher, respectively, in cows fed SSBM than XSBM. Therefore, feeding SSBM might have re- 
Table 11. Effect of dietary treatment on omasal canal flows of individual AA (g/d) in soluble peptides of molecular weights smaller than $3 \mathrm{kDa}$

\begin{tabular}{|c|c|c|c|c|c|c|c|c|}
\hline \multirow[b]{3}{*}{$\mathrm{AA}^{1}$} & \multicolumn{4}{|c|}{$\operatorname{Diet}^{2}$} & \multirow[b]{3}{*}{ SEM } & \multirow{2}{*}{\multicolumn{3}{|c|}{ Contrast ( $P$-value $)$}} \\
\hline & \multirow{2}{*}{$\begin{array}{l}\text { A } \\
\text { (urea) }\end{array}$} & \multirow{2}{*}{$\begin{array}{l}\text { B } \\
\text { (SSBM) }\end{array}$} & \multirow{2}{*}{$\begin{array}{l}\mathrm{C} \\
(\mathrm{XSBM})\end{array}$} & \multirow{2}{*}{$\begin{array}{l}\text { D } \\
(\mathrm{CGM})\end{array}$} & & & & \\
\hline & & & & & & A vs. D & B vs. $\mathrm{C}$ & C vs. D \\
\hline \multicolumn{9}{|l|}{ Essential } \\
\hline Arg & 0.93 & 0.81 & 1.12 & 1.27 & 0.22 & 0.18 & 0.21 & 0.53 \\
\hline His & 1.44 & 1.96 & 1.66 & 1.55 & 0.15 & 0.52 & 0.13 & 0.60 \\
\hline Ile & 1.59 & 1.78 & 1.97 & 1.97 & 0.19 & 0.2 & 0.51 & 1.00 \\
\hline Leu & 2.06 & 2.34 & 2.34 & 2.62 & 0.37 & 0.21 & 0.97 & 0.55 \\
\hline Lys & 1.83 & 1.93 & 2.09 & 1.93 & 0.26 & 0.65 & 0.62 & 0.54 \\
\hline Met & 0.56 & 1.12 & 0.20 & 0.53 & 0.18 & 0.91 & 0.03 & 0.27 \\
\hline Phe & 0.26 & 0.79 & 0.38 & 0.39 & 0.17 & 0.62 & 0.17 & 0.96 \\
\hline Thr & 2.81 & 2.81 & 2.47 & 2.81 & 0.43 & 0.88 & 0.24 & 0.31 \\
\hline Val & 3.76 & 4.93 & 3.43 & 3.51 & 0.50 & 0.36 & $<0.01$ & 0.79 \\
\hline \multicolumn{9}{|l|}{ Nonessential } \\
\hline Ala & 6.55 & 10.88 & 6.04 & 6.87 & 1.65 & 0.81 & 0.03 & 0.58 \\
\hline Asp & 5.23 & 5.80 & 5.61 & 5.32 & 0.76 & 0.92 & 0.81 & 0.66 \\
\hline Cys & 4.55 & 8.15 & 4.03 & 3.77 & 0.94 & 0.36 & $<0.01$ & 0.81 \\
\hline Glu & 5.99 & 5.67 & 4.94 & 6.30 & 1.05 & 0.86 & 0.54 & 0.32 \\
\hline Gly & 4.29 & 5.09 & 4.07 & 4.13 & 0.27 & 0.49 & $<0.01$ & 0.21 \\
\hline Pro & 2.55 & 2.47 & 2.47 & 2.88 & 0.41 & 0.37 & 0.91 & 0.24 \\
\hline Ser & 2.03 & 2.10 & 1.95 & 2.25 & 0.38 & 0.57 & 0.68 & 0.45 \\
\hline Tyr & 0.85 & 0.97 & 0.79 & 0.98 & 0.17 & 0.49 & 0.37 & 0.33 \\
\hline \multicolumn{9}{|l|}{ Total } \\
\hline $\mathrm{g} / \mathrm{d}$ & 47.3 & 59.6 & 45.5 & 49.1 & 5.6 & 0.12 & $<0.01$ & 0.05 \\
\hline$\%$ of TSAA flow & 19.5 & 20.3 & 17.5 & 12.7 & 2.1 & 0.11 & 0.42 & 0.21 \\
\hline$\%$ of TAA flow & 2.80 & 2.34 & 1.63 & 2.13 & 0.47 & 0.20 & 0.18 & 0.30 \\
\hline \multicolumn{9}{|l|}{ Microbial } \\
\hline $\mathrm{g} / \mathrm{d}$ & 3.56 & 2.99 & 2.49 & 4.63 & 0.81 & 0.15 & 0.16 & 0.01 \\
\hline$\%$ of total SPt flow & 7.53 & 5.01 & 5.47 & 9.43 & 5.80 & 0.27 & 0.77 & 0.07 \\
\hline \multicolumn{9}{|l|}{ Dietary } \\
\hline $\mathrm{g} / \mathrm{d}$ & 43.7 & 56.6 & 43.0 & 44.5 & 4.8 & 0.44 & $<0.01$ & 0.64 \\
\hline$\%$ of total SPt flow & 92.5 & 95 & 94.5 & 90.6 & 5.8 & 0.27 & 0.77 & 0.07 \\
\hline
\end{tabular}

${ }^{1} \mathrm{TSAA}=$ total soluble $\mathrm{AA} ; \mathrm{TAA}=$ total $\mathrm{AA} ; \mathrm{SPt}=$ soluble peptides of molecular weight $<3 \mathrm{kDa}$.

${ }^{2} \mathrm{SSBM}=$ solvent soybean meal; XSBM = xylose-treated soybean meal; CGM = corn gluten meal.

Table 12. Effect of dietary treatment on omasal canal flows of individual free AA (g/d)

\begin{tabular}{|c|c|c|c|c|c|c|c|c|}
\hline \multirow[b]{3}{*}{$\mathrm{AA}^{1}$} & \multicolumn{4}{|c|}{$\operatorname{Diet}^{2}$} & \multirow[b]{3}{*}{ SEM } & \multirow{2}{*}{\multicolumn{3}{|c|}{ Contrast ( $P$-value $)$}} \\
\hline & \multirow{2}{*}{$\begin{array}{l}\text { A } \\
\text { (urea) }\end{array}$} & \multirow{2}{*}{$\begin{array}{l}\text { B } \\
(\mathrm{SSBM})\end{array}$} & \multirow{2}{*}{$\begin{array}{l}\mathrm{C} \\
(\mathrm{XSBM})\end{array}$} & \multirow{2}{*}{$\begin{array}{l}\mathrm{D} \\
(\mathrm{CGM})\end{array}$} & & & & \\
\hline & & & & & & A vs. D & B vs. $\mathrm{C}$ & C vs. D \\
\hline \multicolumn{9}{|l|}{ Essential } \\
\hline Arg & 0.2 & 0.2 & 0.2 & 0.4 & 0.2 & 0.49 & 0.69 & 0.53 \\
\hline His & 0.2 & 0.2 & 0.2 & 0.1 & 0.0 & 0.52 & 0.1 & 0.83 \\
\hline Ile & 0.8 & 0.8 & 0.6 & 0.5 & 0.2 & 0.02 & 0.02 & 0.29 \\
\hline Leu & 2 & 2 & 1 & 2 & 1 & 0.99 & 0.13 & 0.26 \\
\hline Lys & 1.2 & 1.1 & 0.8 & 0.8 & 0.3 & 0.03 & 0.08 & 0.78 \\
\hline Phe & 0.7 & 0.8 & 0.4 & 0.7 & 0.2 & 0.99 & 0.09 & 0.21 \\
\hline \multicolumn{9}{|l|}{ Nonessential } \\
\hline Tyr & 0.7 & 0.7 & 0.4 & 0.6 & 0.3 & 0.79 & 0.25 & 0.31 \\
\hline \multicolumn{9}{|l|}{ Total } \\
\hline $\mathrm{g} / \mathrm{d}$ & 5.31 & 5.68 & 3.73 & 4.69 & 1.80 & 0.66 & 0.24 & 0.45 \\
\hline$\%$ of TSAA flow & 1.87 & 1.83 & 1.59 & 1.04 & 0.44 & 0.08 & 0.49 & 0.18 \\
\hline$\%$ of TAA flow & 0.34 & 0.21 & 0.14 & 0.22 & 0.11 & 0.25 & 0.50 & 0.44 \\
\hline \multicolumn{9}{|l|}{ Microbial } \\
\hline $\mathrm{g} / \mathrm{d}$ & 0.40 & 0.28 & 0.20 & 0.44 & 0.13 & 0.91 & 0.4 & 0.06 \\
\hline$\%$ of total FAA flow & 7.53 & 5.01 & 5.47 & 9.43 & 5.8 & 0.15 & 0.38 & 0.17 \\
\hline
\end{tabular}

${ }^{1}$ The following AA were in nondetectable concentrations (detection limit: $0.05 \mathrm{mg}$ of AA-N per L of omasal fluid phase): Met, Thr, Val, Ala, Asp, Cys, Glu, Gly, Pro, and Ser. TSAA = total soluble AA; TAA = total $\mathrm{AA} ; \mathrm{FAA}=$ free AA

${ }^{2} \mathrm{SSBM}=$ solvent soybean meal; XSBM $=$ xylose-treated soybean meal; CGM = corn gluten meal. 
Table 13. Effect of dietary treatments on the omasal flows of total soluble AA

\begin{tabular}{|c|c|c|c|c|c|c|c|c|}
\hline \multirow[b]{3}{*}{ Soluble AA flow ${ }^{1}$} & \multicolumn{4}{|c|}{$\operatorname{Diet}^{2}$} & \multirow[b]{3}{*}{ SEM } & \multirow{2}{*}{\multicolumn{3}{|c|}{ Contrast ( $P$-value $)$}} \\
\hline & \multirow{2}{*}{$\begin{array}{l}\text { A } \\
\text { (urea) }\end{array}$} & \multirow{2}{*}{$\begin{array}{l}\mathrm{B} \\
(\mathrm{SSBM})\end{array}$} & \multirow{2}{*}{$\begin{array}{l}\mathrm{C} \\
(\mathrm{XSBM})\end{array}$} & \multirow{2}{*}{$\begin{array}{l}\mathrm{D} \\
(\mathrm{CGM})\end{array}$} & & & & \\
\hline & & & & & & A vs. D & B vs. $\mathrm{C}$ & C vs. D \\
\hline Total & & & & & & & & \\
\hline $\mathrm{g} / \mathrm{d}$ & 254 & 308 & 266 & 377 & 48 & 0.14 & 0.56 & 0.17 \\
\hline$\%$ of TAA flow & 15.5 & 11.6 & 9.2 & 15.9 & 3.7 & 0.93 & 0.63 & 0.23 \\
\hline Microbial & & & & & & & & \\
\hline $\mathrm{g} / \mathrm{d}$ & 90.3 & 70.7 & 62.4 & 109.5 & 21.8 & 0.29 & 0.57 & 0.2 \\
\hline$\%$ of TSAA flow & 33.2 & 20.6 & 21.7 & 28.8 & 2.6 & 0.29 & 0.74 & 0.22 \\
\hline$\%$ of TAA flow & 5.40 & 1.77 & 2.10 & 5.34 & 2.10 & 0.98 & 0.92 & 0.45 \\
\hline Dietary & & & & & & & & \\
\hline $\mathrm{g} / \mathrm{d}$ & 168 & 242 & 206 & 271 & 25 & $<0.01$ & 0.03 & $<0.01$ \\
\hline$\%$ of TSAA flow & 66.8 & 79.4 & 78.3 & 71.2 & 2.7 & 0.29 & 0.74 & 0.22 \\
\hline$\%$ of TAA flow & 10.7 & 8.0 & 8.2 & 13.1 & 2.8 & 0.56 & 0.97 & 0.4 \\
\hline
\end{tabular}

${ }^{1} \mathrm{TAA}=$ total $\mathrm{AA} ; \mathrm{TSAA}=$ total soluble $\mathrm{AA}$.

${ }^{2} \mathrm{SSBM}=$ solvent soybean meal; XSBM = xylose-treated soybean meal; CGM = corn gluten meal .

sulted in greater formation and accumulation of peptides containing Pro in combination with Met, Gly, and Val, compared with XSBM. Similarly, passage of ruminal peptides (determined in the chemically deproteinized supernatant of rumen fluid) increased with increasing intakes of degradable protein by cows in diets supplemented with either SSBM, extruded SBM, or fish meal (Chen et al., 1987b).

Flows of Ile and Lys in their free form were significantly higher for cows whose diets were supplemented with urea, compared with CGM (Table 12). Cows fed SSBM had higher flows of Ile $(P=0.02)$ and a trend for significantly higher flows of His, Lys, and Phe compared with cows whose diets were supplemented with XSBM.

Despite the alteration of the individual soluble AA flow from the rumen of cows by dietary manipulation observed in the present study, the extent of these changes was relatively small compared with the total flow of each AA. Although the flow of Met in small peptides was 5.6 times higher for cows fed SSBM than for cows fed XSBM (1.12 vs. $0.2 \mathrm{~g} / \mathrm{d}$; Table 11), the 0.92 $\mathrm{g} / \mathrm{d}$ difference represented only $1.3 \%$ of the total flow of Met at the omasal canal (mean $70 \mathrm{~g} / \mathrm{d}$; Table 6).

\section{Omasal Flows of Soluble AA from Microbial and Dietary Origin}

The microbial contribution to total SNAN flows at the omasal canal of cows fed diets containing grass silage, barley, and rapeseed meal averaged 61 (Choi et al., 2002a) and 71\% (Choi et al., 2003) across diets. However, microbial SNAN flows were estimated based on ${ }^{15} \mathrm{~N}$ enrichment of the supernatant of omasal samples that were acidified with $\mathrm{H}_{2} \mathrm{SO}_{4}$ before centrifugation. The addition of a strong acid to digesta samples before removal of microbial cells by centrifugation could have resulted in cell lysis, release of cytoplasmic soluble $\mathrm{N}$, and overestimation of microbial contributions to SNAN flows. On the contrary, in the present study only $25 \%$ of oligopeptides and $7 \%$ of peptides plus FAA flowing at the omasal canal were of microbial origin (Tables 10-12). Although most of the soluble proteins greater than $10 \mathrm{~K}$ were of microbial origin (mean $73 \%$ ), this fraction constituted only $10 \%$ of the total soluble AA flowing at the omasal canal (Table 9). Dietary soluble AA contributed, on average, $73 \%$ of total soluble AA and $10 \%$ of total AA flows (Table 13), indicating a substantial escape of dietary soluble AA from ruminal degradation. These results call into question the validity of assuming that ruminal degradation of the soluble $\mathrm{N}$ fraction (fraction $\mathrm{A}$ ) of feeds incubated in situ occurs at an infinite rate and that the portion of protein that is degraded in the rumen (fraction B) is solely used for microbial protein synthesis, production of ammonia and carbon skeletons, or both.

Soluble AA flows of dietary origin were significantly affected by dietary treatment. Replacing XSBM with CGM resulted in higher flows of total (206 vs. $271 \mathrm{~g} /$ d) and oligopeptide-associated (151 vs. $216 \mathrm{~g} / \mathrm{d}$ ) soluble AA of dietary origin, whereas replacing urea with CGM increased oligopeptide-associated (110 vs. $216 \mathrm{~g} / \mathrm{d}$ ) and total (168 vs. $271 \mathrm{~g} / \mathrm{d}$ ) dietary soluble AA flows (Tables 10 and 13). The flow of soluble peptides of dietary origin in cows fed SSBM was significantly higher than for cows fed XSBM (57 vs. $43 \mathrm{~g} / \mathrm{d}$; Table 11). Differences in DMI among treatments might have accounted for part of these findings.

\section{CONCLUSIONS}

The study of the metabolic and nutritional significance of ruminal peptide and FAA pools to both mi- 
crobes and the host animal depend on accurate and reproducible techniques for isolating and analyzing these fractions. Based on data reported in this study and in the literature, it would seem reasonable to suggest that published contributions of peptides to the ruminal soluble $\mathrm{N}$ pool might have been overestimated because of incomplete precipitation or partial hydrolysis of soluble proteins by acid treatments.

In the present study, small peptides isolated by ultrafiltration contributed between 13 and $20 \%$ of the total AA in the soluble fraction and less than $3 \%$ of the total AA flowing at the omasal canal of cows fed diets differing in the concentration and source of supplemental protein. On the other hand, AA in soluble $3-10 \mathrm{~K}$ oligopeptides averaged $71 \%$, whereas FAA accounted for less than $2 \%$ of total soluble AA flows across diets. Therefore, our results suggest that hydrolysis of oligopeptides (3-10K) was the rate-limiting step during microbial degradation of soluble proteins and that small peptides and FAA were rapidly utilized by ruminal microbes and did not accumulate in the rumen. On average, $73 \%$ of total soluble $\mathrm{AA}$ and $10 \%$ of total AA flows were of dietary origin, indicating a substantial escape of dietary soluble AA from ruminal degradation and calling into question the use of in situ estimations of protein degradation to predict the flow of RUP. Although the omasal flow of some individual AA associated with peptides and oligopeptides was significantly affected by dietary treatment, these changes were relatively small compared with the total flow of AA in their soluble and insoluble forms. The methodology described in the present paper may allow for more accurate quantitation of the ruminal peptide and FAA pools, their variations caused by the diet, and their metabolic and nutritional significance to the ruminal microbes and the host animal.

\section{REFERENCES}

AFRC (Agricultural and Food Research Council). 1992. Nutrient Requirements of Ruminant Animals: Protein. Technical Committee on Responses to Nutrients. Report No. 9. Nutr. Abstr. Rev. (Ser. B) 62:787-835.

Ahvenjärvi, S., A. Vanhatalo, P. Huhtanen, and T. Varvikko. 2000. Determination of reticulo-rumen and whole-stomach digestion in lactating cows by omasal canal or duodenal sampling. Br. J. Nutr. 83:67-77.

AOAC. 1980. Official Methods of Analysis. 13th ed. Association of Official Analytical Chemists International, Washington, DC.

Argyle, J. L., and R. L. Baldwin. 1989. Effects of amino acids and peptides on rumen microbial growth yields. J. Dairy Sci. 72:2017-2027.

Backwell, F. R. C. 1998. Circulating peptides and their role in milk protein synthesis. Pages 69-78 in Peptides in mammalian protein metabolism. G. K. Grimble and F. R. C. Backwell, eds. Portland Press Ltd., London.

Backwell, F. R. C., M. Hipolito-Reis, D. Willson, L. A. Bruce, V. Buchan, and J. C. McRae. 1997. Quantification of circulating peptides and assessment of peptide uptake across the gastrointestinal tract of sheep. J. Anim. Sci. 75:3315-3322.

Bernard, L., B. Chauveau, and D. Remond. 2001. Effect of the methodology on peptide amino acid concentrations in blood and plasma of sheep. Arch. Anim. Nutr. 54:281-296.

Bhatty, R. S. 1972. A note on trichloroacetic acid precipitation of oilseed proteins. Cereal Chem. 49:729-731.

Broderick, G. A., and J. H. Kang. 1980. Automated simultaneous determination of ammonia and total amino acids in ruminal fluid and in vitro media. J. Dairy Sci. 63:64-75.

Broderick, G. A., and R. J. Wallace. 1988. Effects of dietary nitrogen source on concentrations of ammonia, free amino acids and fluorescamine-reactive peptides in the sheep rumen. J. Anim. Sci. 66:2233-2238.

Broderick, G. A., R. J. Wallace, and E. R. Orskov. 1991. Control of rate and extent of protein degradation. Pages 541-592 in Physiological Aspects of Digestion and Metabolism in Ruminants. T. Tsuda, Y. Sasaki, and R. Kawashima, eds. Academic Press, San Diego, CA.

Brotz, P. G., and D. M. Schaefer. 1987. Simultaneous determination of lactic acid and volatile fatty acids in microbial fermentation extracts by gas-liquid chromatography. J. Microbiol. Methods 6:139-144.

Butts, C. A., P. J. Moughan, and W. C. Smith. 1991. Endogenous amino acid flow at the terminal illeum of the rat determined under conditions of peptide alimentation. J. Sci. Food Agric. 55:175-187.

Carro, M. D., S. Lopez, C. Valdes, and J. S. Gonzalez. 1999. Effect of nitrogen form (casein and urea) on the in vitro degradation of cell walls from six forages. J. Anim. Physiol. Anim. Nutr. (Berl.) 81:212-222.

Chen, G., J. B. Russell, and C. J. Sniffen. 1987a. A procedure for measuring peptides in rumen fluid and evidence that peptide uptake can be a rate-limiting step in ruminal protein degradation. J. Dairy Sci. 70:1211-1219.

Chen, G., C. J. Sniffen, and J. B. Russell. 1987b. Concentration and estimated flow of peptides from the rumen of dairy cattle: Effects of protein quantity, protein solubility, and feeding frequency. J. Dairy Sci. 70:983-992.

Chikunya, S., C. J. Newbold, L. M. Rode, X. B. Chen, and R. J. Wallace. 1996. Influence of dietary rumen-degradable protein on bacterial growth in the rumen of sheep receiving different energy sources. Anim. Feed Sci. Technol. 63:333-340.

Choi, C. W., S. Ahvenjarvi, A. Vanhatalo, V. Toivonen, and P. Huhtanen. 2002a. Quantitation of the flow of soluble non-ammonia nitrogen entering the omasal canal of dairy cows fed grass silage based diets. Anim. Feed Sci. Technol. 96:203-220.

Choi, C. W., A. Vanhatalo, S. Ahvenjarvi, and P. Huhtanen. 2002b. Effects of several protein supplements on flow of soluble nonammonia nitrogen from the forestomach and milk production in dairy cows. Anim. Feed Sci. Technol. 102:15-33.

Choi, C. W., A. Vanhatalo, and P. Huhtanen. 2003. Effects of type of grass silage and level of concentrate on the flow of soluble nonammonia nitrogen entering the omasum of dairy cows. J. Anim. Feed Sci. 12:3-22.

France, J., and R. C. Siddons. 1986. Determination of digesta flow by continuous marker infusion. J. Theor. Biol. 121:105-120.

Galibois, I., F. Pitre, G. Parent, and L. Savoie. 1991. Analysis of bound amino acids in the plasma of fed rats: A new preparation procedure. J. Nutr. Biochem. 2:25-30.

Gehrke, C. W., L. L. Wall, Sr., J. S. Absheer, F. E. Kaiser, and R. W. Zumwalt. 1985. Sample preparation for chromatography of amino acids: Acid hydrolysis of proteins. J. AOAC 68:811-821.

Greenberg, N. A., and W. F. Shipe. 1979. Comparison of the abilities of trichloroacetic, picric, sulfosalicylic, and tungstic acids to precipitate protein hydrolysates and proteins. J. Food Sci. 44:735737.

Huhtanen, P., P. G. Brotz, and L. D. Satter. 1997. Omasal sampling technique for assessing fermentative digestion in the forestomach of dairy cows. J. Anim. Sci. 75:1380-1392.

Ipharraguerre, I. R., and J. H. Clark. 2005. Impacts of the source and amount of crude protein on the intestinal supply of nitrogen fractions and performance of dairy cows. J. Dairy Sci. 88(E Suppl.):E22-E37. 
Ipharraguerre, I. R., J. H. Clark, and D. E. Freeman. 2005. Rumen fermentation and intestinal supply of nutrients in dairy cows fed rumen-protected soy products. J. Dairy Sci. 88:2879-2892.

Ipharraguerre, I. R., S. M. Reynal, M. Lineiro, G. A. Broderick, and J. H. Clark. 2007. A comparison of sampling sites, digesta and microbial markers, and microbial references for assessing the postruminal supply of nutrients in dairy cows. J. Dairy Sci. 90:1904-1919.

Klapper, M. H. 1977. The independent distribution of amino-acid near neighbor pairs into polypeptides. Biochem. Biophys. Res. Commun. 78:1018-1024.

Klusmeyer, T. H., R. D. McCarthy, Jr., J. H. Clark, and D. R. Nelson. 1990. Effects of source and amount of protein on ruminal fermentation and passage of nutrients to the small intestine of lactating cows. J. Dairy Sci. 73:3526-3537.

Licitra, G., T. M. Hernandez, and P. J. Van Soest. 1996. Standardization of procedures for nitrogen fractionation of ruminant feeds. Anim. Feed Sci. Technol. 57:347-358.

Littell, R. C., G. A. Milliken, W. W. Stroup, and R. D. Wolfinger. 1996. SAS System for Mixed Models. SAS Inst., Inc., Cary, NC.

McDougall, E. I. 1948. Studies on ruminant saliva 1. The composition and output of sheep saliva. Biochem. J. 43:99-109.

Moughan, P. J., A. J. Darragh, W. C. Smith, and C. A. Butts. 1990. Perchloric and trichloroacetic acids as precipitants of protein in endogenous ileal digesta from the rat. J. Sci. Food Agric. 52:13-21.

Nagel, S. A., and G. A. Broderick. 1992. Effect of formic acid or formaldehyde treatment of alfalfa silage on nutrient utilization by dairy cows. J. Dairy Sci. 75:140-154.

NRC. 2001. Nutrient Requirements of Dairy Cattle. 7th rev. ed. Nat. Acad. Sci., Washington, DC.

Ohara, I., and S. Ariyoshi. 1979. Comparison of protein precipitants for the determination of free amino acids in plasma. Agric. Biol. Chem. 43:1473-1478.

Peterson, P. J., J. Hendtlass, J. C. MacRae, and P. D. Pearce. 1971. Extraction and analysis of free amino acids from sheep digesta. J. Sci. Food Agric. 22:548-550.

Remond, D., L. Bernard, and C. Poncet. 2000. Free and peptide amino acid net flux across the rumen and the mesenteric- and portaldrained viscera of sheep. J. Anim. Sci. 78:1960-1972.

Reynal, S. M., and G. A. Broderick. 2003. Effects of feeding dairy cows protein supplements of varying ruminal degradability. J. Dairy Sci. 86:835-843.
Russell, J. B., C. J. Sniffen, and P. J. Van Soest. 1983. Effect of carbohydrate limitation on degradation and utilization of casein by mixed rumen bacteria. J. Dairy Sci. 66:763-775.

SAS Institute. 1999. SAS/STAT User's Guide (Release 8.1), SAS Inst., Inc., Cary, NC.

Seal, C. J., and D. S. Parker. 1996. Effect of intraruminal propionic acid infusion on metabolism of mesenteric- and portal-drained viscera in growing steers fed a forage diet: II. Ammonia, urea, amino acids, and peptides. J. Anim. Sci. 74:245-256.

Seal, C. J., and D. S. Parker. 1998. Methodological approaches for the quantification of peptide appearance across the gastro-intestinal tract. Pages 43-54 in Peptides in Mamalian Protein Metabolism. G. K. Grimble and F. R. C. Backwell, ed. Portland Press Ltd., London, UK.

Sniffen, C. J., J. D. O'Connor, P. J. Van Soest, D. G. Fox, and J. B. Russell. 1992. A net carbohydrate and protein system for evaluating cattle diets: II. Carbohydrate and protein availability. J. Anim. Sci. 70:3562-3577.

Volden, H., L. T. Mydland, and V. Olaisen. 2002. Apparent ruminal degradation and rumen escape of soluble $\mathrm{N}$ fractions in grass and grass silage administered intraruminally to lactating dairy cows. J. Anim. Sci. 80:2704-2716.

Volden, H., W. Velle, O. V. Sjaastad, A. Aulie, and O. M. Harstad. 2001. Concentrations and flow of free amino acids in ruminal and duodenal liquid of dairy cows in relation to feed composition, time of feeding and level of feed intake. Acta Agric. Scand. 51:35-45.

Wallace, R. J., and N. McKain. 1990. A comparison of methods for determining the concentration of extracellular peptides in rumen fluid of sheep. J. Agric. Sci. (Camb.) 114:101-105.

Webb, K. E., and J. C. Matthews. 1998. Peptide absorption and its significance in ruminant protein metabolism. Pages 1-10 in Peptides in Mammalian Protein Metabolism. G. K. Grimble and F. R. C. Backwell, ed. Portland Press Ltd., London, UK.

Wohlt, J. E., S. L. Chmiel, P. K. Zajac, L. Backer, D. B. Blethen, and J. L. Evans. 1991. Dry matter intake, milk yield and composition, and nitrogen use in Holstein cows fed soybean, fish, or corn gluten meals. J. Dairy Sci. 74:1609-1622.

Yang, C. M. J., and J. B. Russell. 1992. Resistance of proline-containing peptides to ruminal degradation in vitro. Appl. Environ. Microbiol. 58:3954-3958. 